OPEN ACCESS

Edited by:

Paulo Artaxo,

University of São Paulo, Brazil

Reviewed by:

Pérola Castro Vasconcellos, University of São Paulo, Brazil

Maria De Fatima Andrade,

University of São Paulo, Brazil

Gary Salazar,

University of Bern, Switzerland

*Correspondence:

Yasser Morera-Gómez

yasser@ceac.cu,

ymore24@gmail.com

Specialty section:

This article was submitted to

Atmospheric Science,

a section of the journal

Frontiers in Environmental Science

Received: 28 October 2020

Accepted: 05 March 2021

Published: 25 March 2021

Citation:

Morera-Gómez Y, Cong $Z$ and Widory D (2021) Carbonaceous

Fractions Contents and Carbon

Stable Isotope Compositions

of Aerosols Collected

in the Atmosphere of Montreal (Canada): Seasonality, Sources, and Implications.

Front. Environ. Sci. 9:622521. doi: 10.3389/fenvs.2021.622521

\section{Carbonaceous Fractions Contents and Carbon Stable Isotope Compositions of Aerosols Collected in the Atmosphere of Montreal (Canada): Seasonality, Sources, and Implications}

\author{
Yasser Morera-Gómez ${ }^{1,2 *}$, Zhiyuan Cong ${ }^{3}$ and David Widory ${ }^{1}$ \\ 1 Geotop/Université du Québec à Montréal (UQAM), Montréal, QC, Canada, ${ }^{2}$ Centro de Estudios Ambientales \\ de Cienfuegos, Cienfuegos, Cuba, ${ }^{3}$ Key Laboratory of Tibetan Environment Changes and Land Surface Processes, Institute \\ of Tibetan Plateau Research, Chinese Academy of Sciences, Beijing, China
}

With the objective of better understanding the sources and dynamics of carbonaceous fractions of the aerosols present in the atmosphere of Montreal, we implemented here an online wet oxidation/isotope ratio mass spectrometry (IRMS) method to simultaneously measure both water-soluble organic carbon (WSOC) content and the corresponding $\delta^{13} \mathrm{C}$ of aerosol samples collected at four monitoring stations over a 1year period representing distinct types of environmental conditions (i.e., background, road traffic, industrial, and downtown). We coupled these data with the corresponding concentrations of other carbon fractions: total carbon (TC), elemental carbon plus organic carbon $(E C+O C)$, and carbonates. Results show that TC $(6.64 \pm 2.88 \mu \mathrm{g}$ $\left.\mathrm{m}^{-3}\right)$, EC $+\mathrm{OC}\left(4.98 \pm 2.23 \mu \mathrm{g} \mathrm{m}^{-3}\right)$, and carbonates $\left(1.71 \pm 1.09 \mu \mathrm{g} \mathrm{m}^{-3}\right)$ were characterized by lower concentrations in winter and higher ones between spring and early autumn, with all fractions expectedly showing significantly lower concentrations for aerosols collected at the background station. We observed a seasonal dependence of the $\delta^{13} \mathrm{C}_{\mathrm{EC}}+\mathrm{OC}(-25.31 \pm 0.94 \%)$ with the $\mathrm{EC}+\mathrm{OC} /$ total suspended particles (TSP) ratio: (i) an increase of the ratio during late spring, summer and early autumn associated to road traffic emissions characterized by a $\delta^{13} \mathrm{C}$ of $\sim-25 \%$ and (ii) lower ratios during the winter months indicating the influence of two distinct emission sources, a first one with a $\delta^{13} \mathrm{C} \sim-27 \%$, suggesting the local influence of combined biomass burning from residential heating and of fossil fuel combustion, and a second one with a $\delta^{13} \mathrm{C} \sim-21 \%$, likely related to more regional emissions. WSOC $\left(1.14 \pm 0.67 \mu \mathrm{g} \mathrm{m}^{-3}\right)$ presented a similar seasonal pattern for all monitoring stations, with low concentrations in winter, early spring and late autumn that rapidly increased until summer. Our results indicate that this seasonality is controlled by higher anthropogenic contributions from southern 
Canada and northeastern United States regions and probably from biogenic emissions during the warm months. Moreover, $\delta^{13} \mathrm{C}_{\text {WSOC }}(-25.08 \pm 1.47 \%)$ showed a ${ }^{13} \mathrm{C}$ depletion in summer, indicating higher fossil fuel and biogenic contributions, whereas the higher isotope compositions observed in winter may result from the photochemical aging of regional aerosols. Ultimately, we identified the influence of local industrial emissions late in 2013 as well as the impact of aerosol emissions associated to the Lac-Mégantic rail disaster that occurred on July 6, $200 \mathrm{~km}$ east of Montreal.

Keywords: TSP, carbonaceous aerosol, online wet oxidation/IRMS method, water-soluble organic carbon, $\delta^{13} \mathrm{C}-$ isotope

\section{INTRODUCTION}

It has now clearly been established that atmospheric particulate matter (PM) affects our climate (Wurzler et al., 2000), the ecosystems (Grantz et al., 2003; Okin et al., 2011), and human health (Le Tertre et al., 2002; Pope and Dockery, 2006; Batterman et al., 2014), especially in urban areas where it is present in significant concentrations (Zhang et al., 2015). Accordingly, substantial research has been carried out during the last decades focusing on chemically characterizing and on identifying the main components of these aerosols (Perrino, 2010; Karagulian et al., 2015). Most of the individual inorganic species that typically represent more than $1 \%$ of the total PM mass can now be easily determined and their main sources identified (Alastuey et al., 2006; Kim et al., 2007; Viana et al., 2008; Aldabe et al., 2011; Cesari et al., 2016; Mukherjee and Agrawal, 2017).

The carbonaceous part of aerosols, particularly organic ones, has recently been the subject of a particular scientific attention due to the proven deleterious character of some of its compounds in our environment (Ho et al., 2006; Sudheer et al., 2016; Zhao et al., 2018). The carbonaceous material encompasses a wide variety of natural and anthropogenic species with different chemical compositions and structures, and represents between 2 and 5\% of the global aerosol emissions (Smithson, 2002). Carbonaceous particles are traditionally divided into elemental carbon (EC), organic carbon (OC), and inorganic carbon (carbonate), the latter being almost exclusively derived from soil dust (Fisseha et al., 2009). EC is considered as a primary contaminant, that derives exclusively from primary emissions and that is mostly related to combustion sources but also to wild fires. EC undergoes little chemical transformation, which makes it a useful tracer of primary anthropogenic air contaminants (Seinfeld and Pankow, 2003; Ho et al., 2006). The OC fraction are primary and secondary contaminants (with both natural and anthropogenic origins) and are formed by condensation of volatile organic compounds (VOCs) (Richter and Howard, 2000; Seinfeld and Pankow, 2003; Weber et al., 2007). While primary OC particles are mainly generated by combustion and/or biogenic sources, secondary organic carbon (SOC) particles are mainly produced through atmospheric reactions involving gaseous organic precursors (Jones and Harrison, 2005; Górka et al., 2014; Sudheer et al., 2016). The water-soluble organic carbon (WSOC) fraction can represent up to $80 \%$ of the total OC (Wang et al., 2010; Kirillova et al., 2014a;
Bikkina et al., 2017; Zhang et al., 2019). WSOC can easily be incorporated into biological systems, contributing to serious health issues (Mills et al., 2009). Due to its hydrophilic nature WSOC significantly enhances the ability of aerosol particles to act as cloud condensation nuclei (CCN) (Asa-Awuku et al., 2011). Furthermore, once dissolved within cloud droplets, WSOC also modifies the cloud chemistry (Decesari et al., 2000).

Isotope geochemistry has now demonstrated its added value, when combined with other classical chemical approaches, for both identifying the sources and characterizing the processes that control the budget of most of the environmental contaminants (Pavuluri et al., 2013; Das et al., 2017; Dong et al., 2017). This is also true for urban aerosols, where carbon stable isotopes $\left(\delta^{13} \mathrm{C}\right)$ have been widely used to identify sources of the total carbon (TC) in urban $\mathrm{PM}_{10}$ (aerosols with an aerodynamic diameter $<10 \mu \mathrm{m}$ ) (e.g., Widory et al., 2004; Lopez-Veneroni, 2009; Górka et al., 2012). One of the main strengths of this approach is that isotope systematics can usually unambiguously discriminate aerosol emissions of distinct origins (e.g., terrigenous, biogenic, industrial activity, and road traffic; Lopez-Veneroni, 2009; Cao et al., 2011; Ceburnis et al., 2011, 2016; Masalaite et al., 2015; Aguilera and Whigham, 2018). The reported range of $\delta^{13} \mathrm{C}$ for road traffic is from -28.3 to $-24.5 \%$, which is similar to the range of non-vehicular fuel sources such as coal, charcoal, and fireplace emissions ( -30.1 to $-23.4 \%$ ) (Aguilera and Whigham, 2018). Dust particles and marine aerosols, in contrast, are more enriched in ${ }^{13} \mathrm{C}$ with $\delta^{13} \mathrm{C}$ ranging from -25 to $-18 \%$ (Turekian et al., 2003; Ceburnis et al., 2011; Miyazaki et al., 2011; Guo et al., 2016; Aguilera and Whigham, 2018). Among potential biogenic sources C3 plants have $\delta^{13} \mathrm{C}$ ranging from -34.7 to $-24.0 \%$, which is depleted in ${ }^{13} \mathrm{C}$ with respect to the range of $\mathrm{C} 4$ plants $(-22.2$ to $-13.0 \%$ ), but that overlap the range of fossil fuel combustion (Martinelli et al., 2002; Kawashima and Haneishi, 2012; Aguilera and Whigham, 2018). Although the study of $\delta^{13} \mathrm{C}$ isotope compositions in aerosols has become a recognized approach for the identification of their carbon sources, discriminating fossil and non-fossil fuel combustion can be helped by the addition of radioactive carbon $\left({ }^{14} \mathrm{C}\right)$ measurements (Szidat et al., 2004; Ceburnis et al., 2011). Studies have also demonstrated that measuring $\delta^{13} \mathrm{C}$ in the different carbonaceous aerosol fractions (e.g., EC and OC) ultimately enhances the possibility to discriminate the contamination sources and helps identifying the potential secondary processes affecting the atmospheric PM (e.g., Kirillova et al., 2013; Wu et al., 2018). 
But while, to date, most studies have focused on the $\delta^{13} \mathrm{C}$ of the total and inorganic carbon aerosol fractions, less attention has been paid to measuring the carbon isotope compositions of the different organic carbon fractions present in urban aerosols, and specifically the $\delta^{13} \mathrm{C}$ of WSOC (Fisseha et al., 2009; Kirillova et al., 2014b; Pavuluri and Kawamura, 2017; Liu et al., 2018; Zhang et al., 2019). The lack of published $\delta^{13} \mathrm{C}_{\mathrm{WSOC}}$ data is mostly explained by analytical locks inherent to its isotope analysis. However, a recent study by Suto and Kawashima (2018) demonstrated that this difficulty can be alleviated by the recent introduction of an online wet oxidation method, coupling liquid chromatography (LC) and isotope ratio mass spectrometry (IRMS). This technique (LC/IRMS) allows an online and rapid ( $\sim 6 \mathrm{~min})$ carbon isotope analysis of the WSOC fraction by means of a wet oxidation of all the aerosol organic compounds followed by the extraction of the formed $\mathrm{CO}_{2}$ from the liquid phase (Krummen et al., 2004; Suto and Kawashima, 2018). This method has proved its suitability for the carbon isotope characterization of WSOC in PM compared to the traditional combustion method (Kirillova et al., 2010) as it shows a higher sensitivity, which in turn facilitates the analysis of low-concentration samples (Fisseha et al., 2006; Suto and Kawashima, 2018; Zhang et al., 2019).

The comprehension of both the atmospheric processes and the sources of carbonaceous aerosols, and specially their organic fraction, is still limited to date due to the complexity of the dynamics of these compounds (e.g., de Gouw and Jimenez, 2009). Since bulk measurements may mask the dynamic changes that affect critical portions of the aerosol organic pool, research has recently started isolating its different fractions and individual compounds to study their compound-specific isotope analysis (CSIA).

Here, we implemented an approach, that include the online wet oxidation/IRMS method, to isotopically characterize different $\mathrm{C}$ fractions of aerosol samples collected by several air quality monitoring stations disseminated in Montreal over a 1-year period. The main objectives of this study were to better identify the sources of aerosol contamination as well as to characterize the seasonal variation and the atmospheric processes that control the budget of the different fractions of carbonaceous aerosols on the island. Studies have already established associations between ambient air contamination and daily mortality in Montreal (Delfino et al., 1997; Goldberg et al., 2013 and references therein). However, to our knowledge, this study is the first to report carbon isotope compositions of aerosol WSOC in Canada and of any carbonaceous aerosol fraction in Montreal.

\section{MATERIALS AND METHODS}

\section{Samples and Sampling Sites}

Total suspended particles (TSP) samples were collected in collaboration with the Environment Department of Ville de Montréal $^{1}$ over a 1-year period in 2013 through their air quality monitoring stations disseminated across the city and

${ }^{1}$ www.rsqa.qc.ca on the island of Montreal (QC, Canada). The monitoring stations belong to the Réseau de surveillance de la qualité de l'air (RSQA) network and are integrated into the National Air Pollution Surveillance Network (NAPS) (Environment and Climate Change Canada, 2010). The Canadian NAPS network has produced one of the largest and more geographically diverse databases of high quality atmospheric particle measurements and speciation in the world (Brook et al., 1997; DabekZlotorzynska et al., 2011). We also obtained daily PM mass (TSP) and hourly gaseous pollutants (e.g., $\mathrm{O}_{3}, \mathrm{NO}_{2}$, and $\mathrm{CO}$ ) concentrations from the Environment Department of Ville de Montréal (Boulet et al., 2013).

Four monitoring stations (number 03, 06, 13, and 99; Figure 1) were selected as they represent the major environmental conditions encountered on the island in terms of atmospheric contamination (Au Yang et al., 2019): (i) station 03 ("Saint-Jean-Baptiste") is located at the north-eastern end of the island and is typically influenced by local petro-chemical industries, (ii) station 06 ("Anjou") is located close to the intersection of two of the main high-traffic highways (highways 40 and 25) on the island, (iii) station 13 ("Drummond") is located downtown and represents the urban background, whereas iv) station 99 ("Sainte-Anne-de-Bellevue") is located at the western end of the island in a semi-rural environment about $35 \mathrm{~km}$ WSW of Montreal downtown and is more likely to sample regional aerosols generated upstream the city and transported to Montreal (Au Yang et al., 2019).

A 24-h aerosol samples were collected by the Ville de Montreal every 6 days during 2013 on pre-combusted quartz filters, using high volume samplers with an average flow of $1.1 \mathrm{~m}^{3} \mathrm{~min}^{-1}$. Aerosol samples were kept at $4^{\circ} \mathrm{C}$, in the absence of light, until they were analyzed. We selected two samples per month for analysis ensuring that they were taken simultaneously at the four monitoring stations. A total of 12 field blank filters ( 1 blank filter per month) were also selected and analyzed.

\section{Meteorological and Air Quality Conditions in Montreal}

The Island of Montreal is mostly occupied by the City of Montreal (the second largest city in Canada) with a population of 2 million inhabitants (Ramos et al., 2016). The island is bordered on its northern part by the Rivière des Prairies and by the Saint Lawrence River south. Montreal island is located between the $45.40^{\circ}-45.72^{\circ} \mathrm{N}$ and $73.98^{\circ}-73.45^{\circ} \mathrm{W}$ (Figure 1). The island is mostly flat, with the exception of a moderate hill in its center, the Mount Royal (culminating at $234 \mathrm{~m}$ above sea level). The climate is humid continental with severe winters and hot humid summers, and is subject to significant meteorological variations. The predominant wind direction is mostly southwest, followed by northeast winds along the Saint Lawrence River.

The poor air quality on the Island is generally associated to high concentrations of fine particles $\left(\mathrm{PM}_{2.5}\right)$, mainly attributed to residential wood burning, road traffic, industrial activities, fireworks, forest fires, and long-range transport from industrial regions in southern Canada and northeastern United States around the Great Lakes (Jeong et al., 2011; Ramos et al., 2016). Pollution levels are traditionally influenced by reigning weather conditions (Boulet et al., 2013). 2013 totaled 53 poor air quality 


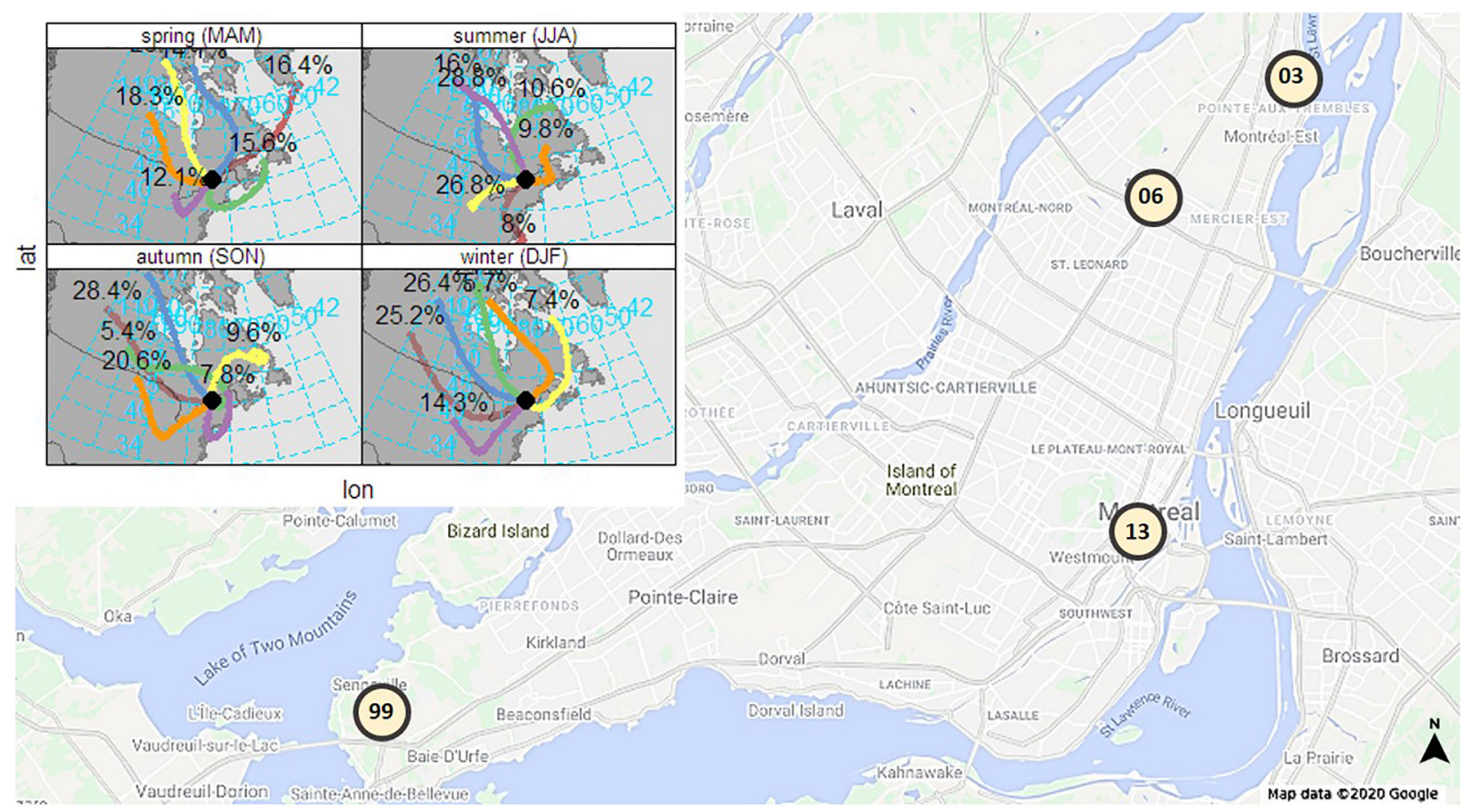

FIGURE 1 | Locations of the aerosol monitoring stations. Modeled back-trajectory clusters for the different seasons of 2013. Station 03 ("Saint-Jean-Baptiste"), station 06 ("Anjou"), station 13 ("Drummond"), and station 99 ("Sainte-Anne-de-Bellevue").

days, of which 15 were due to smog (Boulet et al., 2013). During that year, the local air quality monitoring network indicated that the poor air quality days were mainly observed at station 13 (52 days) and near station 06 (station 07, 20 days). Stations 03 (17 days) and 99 (18 days) showed better air quality conditions. Although the average fine particle concentrations were below the Canadian guidelines $\left(30 \mu \mathrm{g} \mathrm{m}^{-3}\right)$ for all stations, they were still responsible for all the poor air quality days that were recorded (Boulet et al., 2013). The corresponding ozone concentrations also complied with the national guidelines during that period (Boulet et al., 2013).

\section{Chemicals and Standards}

The following chemical reagents and analytical standards were used: sodium peroxodisulfate $\left(\mathrm{Na}_{2} \mathrm{~S}_{2} \mathrm{O}_{8}, \geq 99.0 \%\right.$, Sigma-Aldrich), potassium phosphate monobasic $\left(\mathrm{KH}_{2} \mathrm{PO}_{4}, \geq 99.0 \%\right.$, Thermo Fisher Scientific), phosphoric acid $\left(\mathrm{H}_{3} \mathrm{PO}_{4}, 85.0 \%\right.$, Acros Organics), benzoic acid $\left(\mathrm{C}_{7} \mathrm{H}_{6} \mathrm{O}_{2}\right.$, 99.0\%, Sigma-Aldrich), oxalic acid $\left(\mathrm{C}_{2} \mathrm{H}_{2} \mathrm{O}_{4}, 98.0-102 \%\right.$, Sigma-Aldrich), sucrose $\left(\mathrm{C}_{12} \mathrm{H}_{22} \mathrm{O}_{11}, \geq 99.0 \%\right.$, Fisher Scientific), 1,6-anhydro- $\beta-\mathrm{D}$-glucose (levoglucosan, $\mathrm{C}_{6} \mathrm{H}_{10} \mathrm{O}_{5}, 99.0 \%$, Sigma-Aldrich) and hydrochloric acid ( $\mathrm{HCl}, 36.5-38.0 \%$, Fisher Scientific). All solutions were prepared using Milli-Q water (18.2 M $\Omega$ quality). Once prepared, the mobile phase $\left(0.34 \mathrm{~g}\right.$ of $\mathrm{KH}_{2} \mathrm{PO}_{4}$ in $1 \mathrm{~L}$ of Milli-Q water plus $\mathrm{H}_{3} \mathrm{PO}_{4}$ to attain a $\mathrm{pH}$ of 1.9), acid solution (103 ml of $\mathrm{H}_{3} \mathrm{PO}_{4}$ in $1 \mathrm{~L}$ of Milli-Q water) and oxidizing solution ( $80 \mathrm{~g}$ of $\mathrm{Na}_{2} \mathrm{~S}_{2} \mathrm{O}_{8}$ in $1 \mathrm{~L}$ of Milli-Q water), were first filtrated through $0.20 \mu \mathrm{m}$ nylon filters
(Chromspec) and then degassed in an ultrasonic bath for $35 \mathrm{~min}$ at $35^{\circ} \mathrm{C}$.

\section{Analytical Procedures}

Chemical and isotope analysis were conducted at the Geotop laboratories at Université du Québec à Montréal (UQAM). Figure 2 describes the analytical procedures followed to characterize the different carbon fractions of the TSP samples: TC, inorganic carbon (carbonate), elemental carbon plus organic carbon (EC + OC), and WSOC. The WSOC fraction was analyzed on all selected aerosol samples from each station. On the other hand, TC, EC + OC, and carbonate contents were also analyzed on all selected aerosol samples from stations 06 and 13 but were only measured once a month at stations 03 and 99.

\section{Total Carbon}

Six punches (diameter of $0.68 \mathrm{~cm}$; total area of $2.18 \mathrm{~cm}^{2}$ ) were made on each filter and packed into a tin cup. TC concentrations were then measured using an elemental analyzer (EA; NC 2500, Carlo-Erba Instruments) (Hélie, 2009). The calibration curve was performed analyzing different amounts of three organic analytical standards (OAS): acetanilide $(71.09 \pm 0.21 \% \mathrm{C})$, atropine $(70.54 \pm 0.40 \% \mathrm{C})$, and cyclohexanone-2,4-dinitrophenylhydrazone (51.83 $\pm 0.23 \% \mathrm{C})$. Accuracy was determined by the analysis of a fourth OAS (Low Organic Content Soil Standard, $1.52 \pm 0.05 \% \mathrm{C}$ ) and all results were within $\pm 7 \%$ of the accepted values. The overall analytical uncertainty $(1 \sigma)$ was calculated from the propagation of the uncertainties of the analysis of internal references and the 


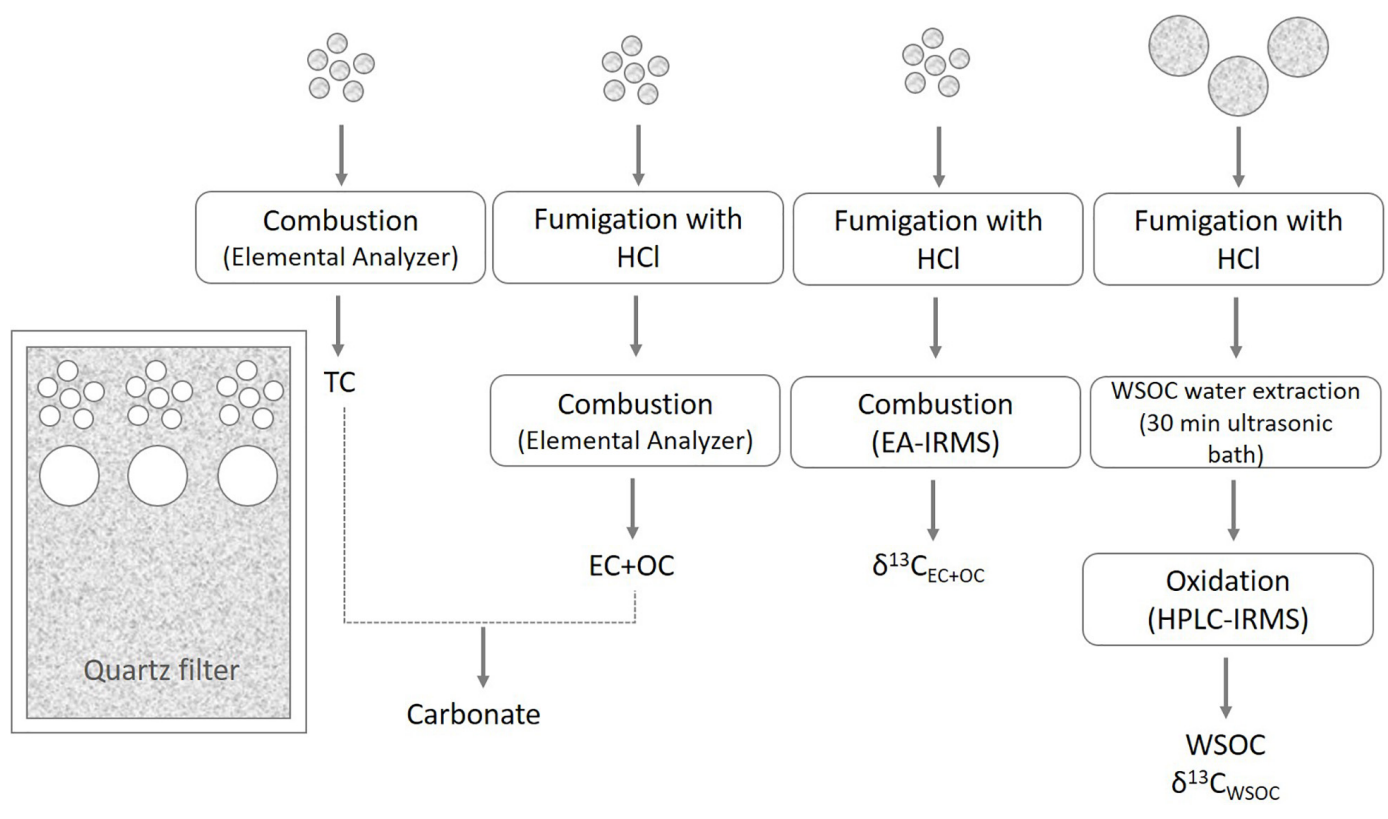

FIGURE 2 | Analytical procedures used to characterize the different aerosol carbon fractions.

samples (e.g., duplicates), and was better than 5\% (Hélie and Hillaire-Marcel, 2021).

We also analyzed several duplicate samples from where we estimated the precision of the method to be $<10 \%$. TC concentrations were all corrected using the average blank value of $3.4 \pm 1.5 \mu \mathrm{g} \mathrm{C} \mathrm{cm}{ }^{-2}(n=2)$ we determined. All results were reported with an associated overall uncertainty $(1 \sigma)$, calculated from the propagation of the analytical uncertainty, the reproducibility (precision) and blank correction (considering its standard deviation) (Hélie and Hillaire-Marcel, 2021).

\section{Elemental Carbon + Organic Carbon and Carbonates}

For analyzing the EC + OC content, 6 filter punches $(0.68 \mathrm{~cm}$ in diameter) were fumigated under $\mathrm{HCl}$ vapors for $24 \mathrm{~h}$ in order to remove carbonates (Fisseha et al., 2009). Fumigated punches were then packed into a tin cup and measured by EA following the procedure described above. The difference between the fumigated and TC carbon contents was considered as representing the carbonate fraction of the aerosol samples. Acidification by $\mathrm{HCl}$ vapors efficiently $(\sim 100 \%)$ removes carbonates and allows to measure accurate $\mathrm{OC}$ concentrations and corresponding $\mathrm{C}$ isotope compositions ( $\delta^{13} \mathrm{C}_{O C}$ ) (e.g., Komada et al., 2008).

The stable $\mathrm{C}$ isotope composition of the $\mathrm{EC}+\mathrm{OC}$ fraction $\left(\delta^{13} \mathrm{C}_{\mathrm{EC}}+{ }_{\text {OC }}\right)$ was determined using new fumigated filter punches $(0.68 \mathrm{~cm}$ in diameter). Punches were packed into a tin capsule that was further introduced into an EA (Vario MICROCube, Elementar, Hanau, Germany) coupled to an Isotope Ratio Mass Spectrometer (IRMS, IsoPrime 100, Cheadle, United Kingdom) operating in continuous flow mode for determining their corresponding $\delta^{13} \mathrm{C}$. The number of punches was adjusted to obtain a similar amount of $\mathrm{CO}_{2}$ on mass $\mathrm{m} / \mathrm{z}=44$ on the IRMS for all samples based on the content of EC + OC.
Carbon isotope compositions were expressed as $\delta^{13} \mathrm{C}$ values, which represent the relative difference expressed in per mil $(\% 0)$ between the isotope ratio of the sample and that of the standard Vienna Pee Dee Belemnite (VPDB) (Suto and Kawashima, 2018):

$$
\delta^{13} C(\% \text { vs. VPDB })=\left[\left(R_{\text {sample }} / R_{V P D B}-1\right)\right] \times 1,000
$$

where $R{ }^{13} \mathrm{C} /{ }^{12} \mathrm{C}$ and $R_{V P D B} 0.0111802$.

$\delta^{13} \mathrm{C}$ values were calibrated using two international certified reference materials: IAEA-603 $\left(\delta^{13} \mathrm{C}=2.46 \pm 0.01 \% 0\right)$ and IAEA-CH-7 $\left(\delta^{13} \mathrm{C}=-32.15 \pm 0.05 \%\right)$. Three internal reference materials leucine $\left(\delta^{13} \mathrm{C}=-28.73 \pm 0.06 \% 0\right)$, sucrose $(-11.85 \pm 0.04 \%)$ and Animal tissue (DORM-2; $-17.04 \pm 0.11 \%$ ) were blind analyzed to evaluate the accuracy of the calibration that was within $0.03 \%$ of the accepted values. The overall analytical uncertainty $(1 \sigma)$ was better than $0.05 \%$. We also ran several duplicate samples and obtained a precision of $0.08 \%$.

All samples were also corrected using field blanks (average $\delta^{13} \mathrm{C}$ of $\left.-29.70 \pm 0.81 \%, n=2\right)$ and the isotope mass balance equations described in Turekian et al. (2003). The final values were reported with an overall uncertainty $(1 \sigma)$ based on the propagation of the analytical uncertainty, the reproducibility (precision) and blank correction (Hélie and Hillaire-Marcel, 2021).

\section{Water-Soluble Organic Carbon}

Prior the WSOC extraction, three filter punches $(1.0 \mathrm{~cm}$ in diameter; total area of $9.4 \mathrm{~cm}^{2}$ ) were first fumigated with $\mathrm{HCl}$ to remove carbonates. WSOC was then extracted plunging the three filter punches into vials filled with $8 \mathrm{ml}$ of Milli-Q water, in an ultrasonic bath for $30 \mathrm{~min}$ (Kirillova et al., 2010; 
Suto and Kawashima, 2018). The solution was ultimately filtered with a $0.45 \mu \mathrm{m}$ syringe filter (Sarstedt) to remove suspended particles. WSOC concentration and corresponding carbon isotope composition $\left(\delta^{13} \mathrm{C}_{\mathrm{WSOC}}\right)$ were immediately analyzed employing the online wet oxidation/IRMS method proposed by Suto and Kawashima (2018), a relatively novel technique that allows an online and rapid analysis ( $\sim 6 \mathrm{~min})$. Our wet oxidation/IRMS system is composed of a LC system (Thermo Scientific Dionex Ultimate 3000, Germering, Germany) coupled to an IRMS instrument (Thermo Scientific Delta V Advantage, Bremen, Germany) via an IsoLink interface (Thermo Scientific). The mobile phase and acid solution flow rates were set at 300 and $50 \mu \mathrm{L} \mathrm{min}{ }^{-1}$, respectively, whereas the oxidizing solution flow rate was set at $14-17 \mu \mathrm{L} \mathrm{min}^{-1}$ in order to guarantee a complete oxidation of the sample. The injection volume was $20 \mu \mathrm{L}$.

Carbon isotope compositions $\left(\delta^{13} \mathrm{C}_{\mathrm{WSOC}}\right)$ were calibrated using four different internal standards overlapping the range of $\delta^{13} \mathrm{C}$ values expected in aerosol samples (e.g., Fisseha et al., 2009; Kirillova et al., 2013; Suto and Kawashima, 2018; Zhang et al., 2019): benzoic acid $\left(\delta^{13} \mathrm{C}=-29.80 \pm 0.05 \%\right.$ ), oxalic acid $\left(\delta^{13} \mathrm{C}=-6.46 \pm 0.05 \% 0\right)$, sucrose $\left(\delta^{13} \mathrm{C}=-11.76 \pm 0.07 \% 0\right)$, and levoglucosan $\left(\delta^{13} \mathrm{C}=-25.44 \pm 0.07 \%\right) . \delta^{13} \mathrm{C}$ of the internal standards were measured by EA/IRMS following the procedure described at section "Elemental Carbon + Organic Carbon and Carbonates." Each standard was measured between 5 and 7 times and the average $\delta^{13} \mathrm{C}$ values were used to calibrate the $\delta^{13} \mathrm{C}$ measured by LC-IRMS (Supplementary Figure 1). The calibration was performed measuring standard solutions with similar $\mathrm{C}$ contents $\left(\sim 10 \mu \mathrm{g} \mathrm{mL} \mathrm{m}^{-1}\right)$. The calibration curve was established before each sample run, measuring each sample in triplicate.

The determination of the WSOC content was performed by means of a calibration of the sample peak areas against the carbon content of a standard solution (Zhang et al., 2019). The sample peak area is proportional to its carbon content, which allows to ultimately quantify the amount of $\mathrm{CO}_{2}$ formed by oxidizing the samples. The calibration was performed using different $\mathrm{C}$ concentrations of benzoic acid dissolved in Milli-Q water: 1, 3, $6,9,12,24$, and $48 \mu \mathrm{g} \mathrm{mL}^{-1}$ (Supplementary Figure 1). The calibration curve was also established before each sample run, measuring each standard solution in triplicate.

One levoglucosan standard sample $\left(9.4 \mu \mathrm{g} \mathrm{C} \mathrm{mL}^{-1}\right.$ and $\delta^{13} \mathrm{C}=-25.44 \pm 0.07 \%$ ) was measured at least every ten samples in order to check the accuracy of the method. At the same time, an internal and external duplicated sample was measured (at least one every 10 samples) to determine the analytical and overall precision of the method, respectively. Accuracies of $<3 \%$ (for an average recovery of $100.8 \pm 2.1 \%$ ) and of $<0.11 \%$ were found for the determination of WSOC and $\delta^{13} \mathrm{C}_{\mathrm{WSOC}}$, respectively. In addition, the analytical and overall precisions were 2.2 and $3.9 \%$ for WSOC and 0.14 and $0.25 \%$ for $\delta^{13} \mathrm{C}_{\text {WSOC }}$, respectively.

All values were corrected using field blank analyses (average WSOC of $1.29 \pm 0.16 \mu \mathrm{g} \mathrm{cm}^{-2}$ and $\delta^{13} \mathrm{C}$ of $-25.86 \pm 0.46 \%$, $n=12$ ). As field blanks were analyzed following the same procedure than the one described above, this correction not only includes correction for the contributions of field blanks but also for the contribution of potential procedural blanks (reagents,
Milli-Q water, ...). Nevertheless, we also ran several procedural blanks interspersed with the raw data and standards in each batch and checked that their $\mathrm{C}$ contents (average of $11.4 \pm 5.1$ ng C) were always lower than those of the field blank samples $(30.3 \pm 3.8 \mathrm{ng}$ C). From the procedural blank C contents we obtained we estimated that the WSOC detection limit (DL) was $34.3 \mathrm{ng} \mathrm{C}$ (=3 times the $\mathrm{C}$ content of the procedural blanks) and the quantification limit (QL) was $114 \mathrm{ng} C$ (=10 times the C content of the procedural blanks). All results are reported using the overall uncertainty $(1 \sigma)$ calculated based on the propagation of the analytical uncertainty, the reproducibility (precision) and blank correction (Hélie and Hillaire-Marcel, 2021).

The relationships between the measured $\delta^{13} \mathrm{C}$, the $\mathrm{C}$ content and the peak area for the benzoic acid standard solutions are shown in Supplementary Figure 2. The absolute differences between replicated standard samples for $\delta^{13} \mathrm{C}$ was $<0.05 \%$ $(\mathrm{SD}<0.03 \% 0)$ except for lower $\mathrm{C}$ contents $(<0.12 \mu \mathrm{g})$ where it was $<0.5 \%$ ( $\mathrm{SD}<0.4 \% 0)$. However, a negative dependency between the $\delta^{13} \mathrm{C}$ values and the $\mathrm{C}$ content was observed, indicating that only $\mathrm{C}$ contents $\geq 0.12 \mu \mathrm{g}$ yielded reliable $\delta^{13} \mathrm{C}$ values within $\pm 0.5 \%$ of the target value (measured by EA/IRMS). Thus, the minimum WSOC amount (DL) for measuring $\delta^{13} \mathrm{C}_{\text {WSOC }}$ was $120 \mathrm{ng} \mathrm{C}$, which is similar to the QL for the analysis of WSOC (114 $\mathrm{ng} \mathrm{C}$ ). This means that our method allows the determination of both the WSOC content and its corresponding $\delta^{13} \mathrm{C}_{\mathrm{WSOC}}$ from a single analysis of about $6 \mathrm{~min}$.

This DL is comparable to the $150 \mathrm{ng} \mathrm{C}$ reported by Fisseha et al. (2006) for the wet oxidation/IRMS method but significantly lower than the one reported for the combustion $(\sim 100 \mu \mathrm{g}$; Fisseha et al., 2006) or other instrument configurations using the wet oxidation/IRMS method ( $\geq 800$ ng C; Kawashima et al., 2018; Suto and Kawashima, 2018; Zhang et al., 2019). Together with the significant reduction of the analysis time ( $\sim 6 \mathrm{~min})$, this constitutes the main advantage of our method, especially for low-concentration samples.

Ultimately, and prior to run the first batch of samples, we also conducted linearity (varying the injection volume from 5 to $50 \mu \mathrm{L}$ at a constant $\mathrm{C}$ concentration) and reproducibility (repeated analysis using a constant injection volume of $20 \mu \mathrm{L}$ ) tests with aerosol samples to ensure the stability of the method (Supplementary Figure 3). The SD for the measured $\delta^{13} \mathrm{C}$ from both experiments was 0.12 and $0.14 \%$, respectively. Moreover, the relative standard deviation (RSD) calculated from the peak area values (proportional to the WSOC content) obtained during the reproducibility test showed an RSD of $1.5 \%$. These results confirmed the stability and feasibility of our method for analyzing atmospheric PM samples.

\section{Sampling Impact on WSOC Measurements}

Studies (McDow and Huntzicker, 1990; Turpin et al., 2000; Weber et al., 2007; Kim et al., 2016) have demonstrated that aerosols collected on quartz fiber filters can also adsorb gaseous OC (i.e., overestimating concentrations; positive artifact) and/or lose semi-VOCs (i.e., underestimating concentrations; negative artifact), which will ultimately harm the determination of the WSOC content. Several methods have traditionally been used to compensate for these organic sampling artifacts including blank 
subtraction, backup filter adjustment, prefilter organic vapor denuders, regression intercept, among others (Subramanian et al., 2004; Watson et al., 2009). Here, we used field blank filters to correct for any artifact that would have been introduced during the sample collection and handling processes. The regression intercept method was also employed to estimate the magnitude of the artifacts resulting from active sampling: we observed a significant linear relationships between the TSP and blankcorrected WSOC concentrations [WSOC $=(0.04 \pm 0.01)$ TSP$\left(0.16 \pm 0.12 \mu \mathrm{g} \mathrm{m}^{-3}\right), R^{2}=0.69, p<0.01$, Figure 3] for samples collected at background station 99. This intercept value, representing $17 \%$ of the annual average WSOC is not significantly different from zero ( $t$-value $=-0.52, p>0.6)$. This indicates a minimal sampling artifact. For the other sampling stations (\#03, 06, and 13) similar significant correlations were also observed, but only during the summer months (Figure 3). The corresponding intercepts, although they were not significantly different from zero ( $t$-test, $p<0.05$ ), on average, account for a positive artifact of $10-21 \%$ of the measured WSOC concentrations.

Studies have shown that the magnitude of positive artifacts tend to decrease as the sampling period and face velocity increase (McDow and Huntzicker, 1990; Turpin et al., 2000; Watson et al., 2009). Here, we collected aerosols over $24 \mathrm{~h}$ and the face velocity ranged from 38 to $52 \mathrm{~cm} \mathrm{~s}^{-1}$. The authors also showed that artifacts depend on the sampling location and season, tending to be more important in urban areas, vs. rural areas, due to higher semi-VOCs concentrations and more important in summer compared to winter. In addition, Watson et al. (2009) also noticed that the intercept method likely overestimates positive artifacts as the high summer sulfate concentrations bias the relationships existing between the PM mass and the OC contents. Based on this, we ultimately considered that the artifacts were minimal along the year for all monitoring stations but that relatively small artifact contributions $(<21 \%)$ are expected during summer at the urban, road-traffic and industrial sampling sites.

\section{Data Analysis}

We investigated our datasets using polar plots, conditional bivariate probability functions $(\mathrm{CBPF})$ and concentration weighted trajectories (CWT) to better understand the respective impacts of local and regional aerosol sources. Calculations were made using the OpenAir R package (Carslaw, 2015).

To compute the CBPF (Uria-Tellaetxe and Carslaw, 2014; Squizzato et al., 2017), the same 24-h measured values of each studied variable was assigned to each hourly wind data available. Hourly meteorological parameters (wind speed and direction) were obtained from the monitoring station located

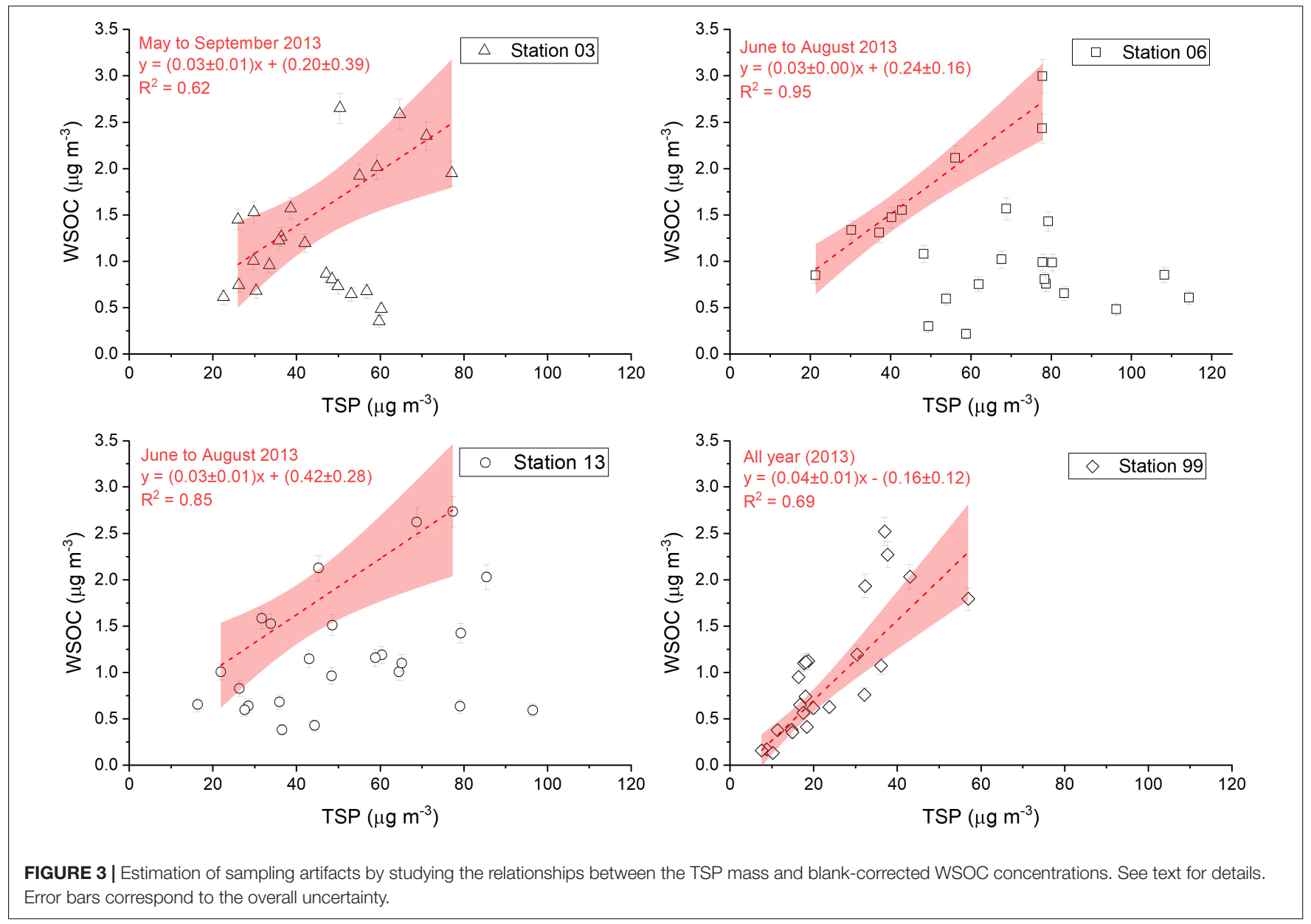


at Pierre-Elliott-Trudeau International Airport (Environment and Climate Change Canada, 2010). For CWT (Hsu et al., 2003; Cheng et al., 2013), 120 and 240-h back-trajectories were computed using the Hybrid Single Particle Lagrangian Integrated Trajectory (HYSPLIT) model and the Global NOAANCEP/NCAR reanalysis data files (Draxler and Rolph, 2015).

As discussed in Squizzato and Masiol (2015), back-trajectories are potentially associated with large uncertainties and may be highly variable when run at different hours within a single day. This may cause further uncertainty when associated to daily pollutant data. To overcome large uncertainties, the confidence associated to back-trajectories is traditionally tested using different starting heights and hours. The use of multiple trajectory based models over long periods may yield even more robust results. In this study, back-trajectories were run at 3$\mathrm{h}$ intervals with an increase of $1-\mathrm{h}$, starting at 500, 1,000, and $2,500 \mathrm{~m}$ above ground level for each day during 2013, using grid cells of $2.5^{\circ} \times 2.5^{\circ}$. Three different altitudes were initially tested to help with source identification (Aldhaif et al., 2020). However, the three altitudes always yielded similar results (e.g., CWT). Therefore, results in this study were presented using an height of $500 \mathrm{~m}$ above ground level.

A non-parametric Kruskal-Wallis ANOVA test (at 0.05 level), followed by multiple comparisons post hoc, were performed to compare the concentrations of the different carbon fractions between our monitoring stations. In addition, hourly data of gaseous pollutants were used to test if they had any relation with the investigated carbonaceous fractions in this work. A locally weighted polynomial regression (LOWESS) function was used to illustrate the temporal variability of each of these pollutants.
Plots and statistical analysis were carried out using the Origin (version 9.0, Origin Lab Corporation, Northampton, MA, United States) and IBM SPSS (version 25, IBM Corp., New York, United States) softwares.

\section{RESULTS}

\section{Chemical and Isotope Characterization of the Different Aerosol Carbon Fractions}

The contents of the different carbon fractions and their corresponding stable isotope composition $\left(\delta^{13} \mathrm{C}\right)$ of the aerosols collected at stations 03, 06, 13, and 99 are reported in Supplementary Table 1 in the Supplementary Material section. An statistical summary of the concentrations and $\delta^{13} \mathrm{C}$ of the different carbon fractions in TSP aerosols is presented in Table $\mathbf{1 .}$

\section{Characteristics of the Carbon Fractions}

Total carbon content in the aerosol samples from the four monitoring stations ranged between 0.88 and $13.27 \mu \mathrm{g} \mathrm{m}^{-3}$ $\left(6.64 \pm 2.88 \mu \mathrm{g} \mathrm{m}^{-3}\right.$, average \pm standard deviation $) . \mathrm{EC}+\mathrm{OC}$ concentrations varied from 0.50 to $11.13 \mu \mathrm{g} \mathrm{m}^{-3}$ (4.98 \pm 2.23 $\left.\mu \mathrm{g} \mathrm{m}^{-3}\right)$. Carbonate contents ranged from 0.18 to $5.23 \mu \mathrm{g} \mathrm{m}^{-3}$ $\left(1.71 \pm 1.9 \mu \mathrm{g} \mathrm{m}^{-3}\right)$. WSOC contents varied from 0.13 to $3.00 \mu \mathrm{g}$ $\mathrm{m}^{-3}\left(1.14 \pm 0.67 \mu \mathrm{g} \mathrm{m}^{-3}\right)$.

Although most of the TC mass is concentrated in the finest PM fractions (up to 90\%; Sudheer et al., 2016), our results showed that the carbonaceous fractions studied here were significantly contributing in our TSP aerosols samples (from 5 to 26\%). For all carbon fractions, there was a tendency to observe the lowest

TABLE 1 | Summary of the concentrations (in $\mu \mathrm{g} \mathrm{m}^{-3}$ ) and carbon stable isotope compositions $\left(\delta^{13} \mathrm{C} ; \%\right)$ of different carbon fractions in TSP aerosols collected at four monitoring stations in Montreal during 2013.

\begin{tabular}{|c|c|c|c|c|c|c|c|}
\hline & TSP & $\delta^{13} \mathrm{C}_{\text {wsoc }}$ & WSOC & $\mathrm{TC}$ & $E C+O C$ & Carbonate & $\delta^{13} \mathrm{C}_{\mathrm{EC}}+\mathrm{OC}$ \\
\hline \multicolumn{8}{|l|}{ Station 03} \\
\hline Average & $45.95^{a}$ & -25.85 & 1.26 & $6.20^{\mathrm{a}}$ & 4.39 & $1.80^{\mathrm{a}}$ & -25.72 \\
\hline Minimum & 22.52 & -32.00 & 0.36 & 3.09 & 2.15 & 0.69 & -26.90 \\
\hline Maximum & 77.08 & -23.63 & 2.65 & 11.65 & 6.95 & 5.23 & -24.52 \\
\hline SD & 15.24 & 2.07 & 0.68 & 2.49 & 1.75 & 1.21 & 0.72 \\
\hline \multicolumn{8}{|l|}{ Station 06} \\
\hline Average & $66.19^{b}$ & -25.04 & 1.13 & $7.55^{\mathrm{a}}$ & $5.53^{a}$ & $2.02^{\mathrm{a}}$ & -25.74 \\
\hline Minimum & 21.30 & -27.64 & 0.22 & 2.96 & 2.21 & 0.29 & -26.58 \\
\hline Maximum & 114.34 & -23.19 & 3.00 & 13.06 & 8.97 & 4.85 & -23.76 \\
\hline SD & 23.47 & 1.30 & 0.66 & 2.54 & 1.89 & 1.23 & 0.63 \\
\hline \multicolumn{8}{|l|}{ Station 13} \\
\hline Average & $50.95^{a b}$ & -24.75 & 1.19 & $7.57^{\mathrm{a}}$ & $5.79^{a}$ & $1.78^{a}$ & -25.06 \\
\hline Minimum & 16.33 & -26.72 & 0.38 & 3.14 & 2.02 & 0.18 & -26.00 \\
\hline Maximum & 96.50 & -23.34 & 2.74 & 13.27 & 11.13 & 4.45 & -21.50 \\
\hline SD & 22.22 & 0.81 & 0.65 & 2.66 & 2.32 & 0.93 & 0.95 \\
\hline \multicolumn{8}{|l|}{ Station 99} \\
\hline Average & $23.21^{c}$ & -24.68 & 0.96 & $3.39^{b}$ & $2.83^{b}$ & $0.79^{b}$ & -24.56 \\
\hline Minimum & 7.53 & -26.81 & 0.13 & 0.88 & 0.50 & 0.24 & -25.79 \\
\hline Maximum & 56.93 & -21.91 & 2.52 & 6.78 & 5.82 & 1.48 & -22.48 \\
\hline SD & 12.29 & 1.18 & 0.69 & 1.92 & 1.70 & 0.35 & 1.05 \\
\hline
\end{tabular}

SD: standard deviation. The different superscript letters refer to significant differences identified at the 0.05 level by the Kruskal-Wallis ANOVA test. 
concentrations at station 99 (Kruskal-Wallis ANOVA test at 0.05 level, Table 1), located at the western end of the island, that is representing the local background (e.g., Au Yang et al., 2019). The rest of the stations showed similar results for all carbon fractions, suggesting a homogeneous influence of carbonaceous aerosols for most of the urban and industrial parts of island covered by these stations. Interestingly, the difference between the $\mathrm{C}$ concentrations at station 99 and at the others was lower, 15$24 \%$ on average for the WSOC, compared to $35-60 \%$ for the TC, $\mathrm{EC}+\mathrm{OC}$ and carbonate fractions. This may suggest that while the WSOC fraction is mostly dominated by regional emissions, other fractions appear to be more influenced by local ones. This is consistent with the findings of Jeong et al. (2011) who estimated that only less than $51 \%$ of the $\mathrm{PM}_{2.5}$ mass, the size fraction where WSOC is most present (Ho et al., 2006; Pavuluri et al., 2013), result of local emissions in Montreal.

\section{$\delta^{13} \mathrm{C}$ Isotope Compositions}

The $\mathrm{EC}+\mathrm{OC}$ carbon isotope compositions $\left(\delta^{13} \mathrm{C}_{\mathrm{EC}}+{ }_{\mathrm{OC}}\right)$ in aerosol samples from stations 03, 06, 13, and 99 varied from -26.90 to $-21.51 \%$ ( $-25.31 \pm 0.94 \%)$. The $\delta^{13} \mathrm{C}_{\text {WSOC }}$ values, on the other hand, varied from -32.00 to $-21.91 \%$ $(-25.08 \pm 1.47 \%)$. The $\delta^{13} \mathrm{C}_{\text {WSOC }}$ fractions were generally more positive than the corresponding $\mathrm{EC}+\mathrm{OC}$ carbon isotope compositions and presented a higher variability (i.e., higher standard deviations). Station 03 was a clear exception with several aerosol samples presenting $\delta^{13} \mathrm{C}_{\mathrm{WSOC}}$ values between -32 and $-27 \%$ (these values are discussed later in the discussion section as they may be related to specific local emissions). Similarly to the C concentrations, the $\delta^{13} \mathrm{C}$ shift between the anthropized stations (stations 03, 06, and 13) and the semi-rural site (station 99) was more pronounced for the EC + OC fraction than the WSOC one, suggesting that the isotope approach applied to the different $\mathrm{C}$ fractions may also be a good proxy to better constrain the origin of carbon in aerosols.

\section{Status of WSOC Worldwide}

Due to analytical limitations, to our knowledge, the studies that have included WSOC in the carbon isotope characterization of the different aerosol $\mathrm{C}$ fractions are scarce. We are providing a summary of their results at Supplementary Table 2. The WSOC contents in our TSP samples (overall average value of $1.14 \pm 0.67 \mu \mathrm{g} \mathrm{m}^{-3}$ ) are generally lower than those reported worldwide. Still, similar concentrations have been reported for both rural and urban environments, and for different PM sizes (TSP, $\mathrm{PM}_{10}$, and $\mathrm{PM}_{2.5}$ ) in Stockholm (Kirillova et al., 2010), Sapporo (Miyazaki et al., 2012; Pavuluri et al., 2013; Pavuluri and Kawamura, 2017), Hanimaadhoo island (Kirillova et al., 2013), Gosan (Kirillova et al., 2014a), Zurich (Szidat et al., 2004), and Ahmedabad (Sudheer et al., 2016). $\delta^{13} C_{W S O C}$ values show a wide range worldwide, from -27.6 to $-17.5 \%$ (Supplementary Table 2). However, most studies, including ours, have $\delta^{13} \mathrm{C}_{\mathrm{WsOC}}$ values falling in the range of -27 to $-21 \%$. Similar to our $\delta^{13} C_{T C}$ values in those studies generally present less variability and are more ${ }^{13} \mathrm{C}$-depleted compared to the WSOC fraction. WSOC compounds in aerosols may come from a wide range of primary sources but also form secondary processes that can induce large isotope fractionations (Szidat et al., 2004; Kirillova et al., 2014a). In addition to the carbon isotope fractionation occurring during the production of primary particles and gaseous precursors (e.g., Widory, 2006), the atmospheric transport and processing of these carbonaceous aerosols (e.g., secondary formation from gaseous precursors by atmospheric oxidation or photochemical aging) may result in additional isotope fractionation (Iannone et al., 2003; Anderson et al., 2004; Kirillova et al., 2014a; Zhang et al., 2019). Therefore, $\delta^{13} \mathrm{C}_{\text {WSOC }}$ can be particularly useful to characterize not only emission sources but also the participating atmospheric processes.

\section{DISCUSSION}

\section{Temporal Variability and Pollution Events Total Carbon}

Time variations for TC, EC + OC, carbonate, WSOC, $\delta^{13} \mathrm{C}_{\mathrm{EC}}+$ OC, and $\delta^{13} \mathrm{C}_{\text {WSOC }}$, measured for each station, are showed in Figure 4. We used a LOWESS function to evaluate the seasonality of each parameter. Figure 4 shows that TC and EC + OC concentrations were similar at stations 06 and 13 and characterized by low values in winter and maximum values in spring, summer, and early autumn. A slight increase was observed at station 03 in spring, with the highest concentrations occurring between late summer and early autumn. Meanwhile, at station 99, TC and EC + OC fractions displayed a different pattern with a single maximum peak in summer. Carbonates distributions at stations 03,06 , and 13 were similar to those of the corresponding TC fraction but with minimum values recorded in June at stations 03 and 06. Significantly lower values associated to different variability characterized carbonates at station 99. In addition, at each station, the higher concentrations (75 percentile) were associated to distinct parts of the island (Supplementary Figure 4). This may indicate that carbonates have a local origin that could be related to construction activities, soil dust or resuspension by road traffic.

All year long, and especially between spring and early autumn, these $\mathrm{C}$ fractions were generally higher at station 06 (high traffic) and 13 (Downtown), where a higher influence of urban transportation is expected. Traffic-related emissions are known to contribute significantly to the PM mass in Montreal (Jeong et al., 2011). In fact, the EC + OC fraction in our TSP aerosol samples significantly increased, up to $20 \%$, during summer and early autumn (Supplementary Figure 5). It is also known that $\mathrm{NO}_{x}$ are good proxies of combustion emissions, especially from road traffic (Kendrick et al., 2015; Malley et al., 2018). Our results identify two distinct $\mathrm{NO}_{2}$ peaks between late April and early May and between late September and early October (Supplementary Figure 6). These two $\mathrm{NO}_{2}$ peaks correspond to the highest TC concentrations (Figure 4) in our aerosol samples. In general, higher EC + OC concentrations (CBPF; 75th percentile; Figure 5) at stations 03, 06, and 13 appear to be mainly associated to emissions generated along major highways and their intersections, while at station 99 they appear to correlate with the eastern wind directions, where most of the island urban region is located (Figure 1). Samaali et al. (2011) implemented 


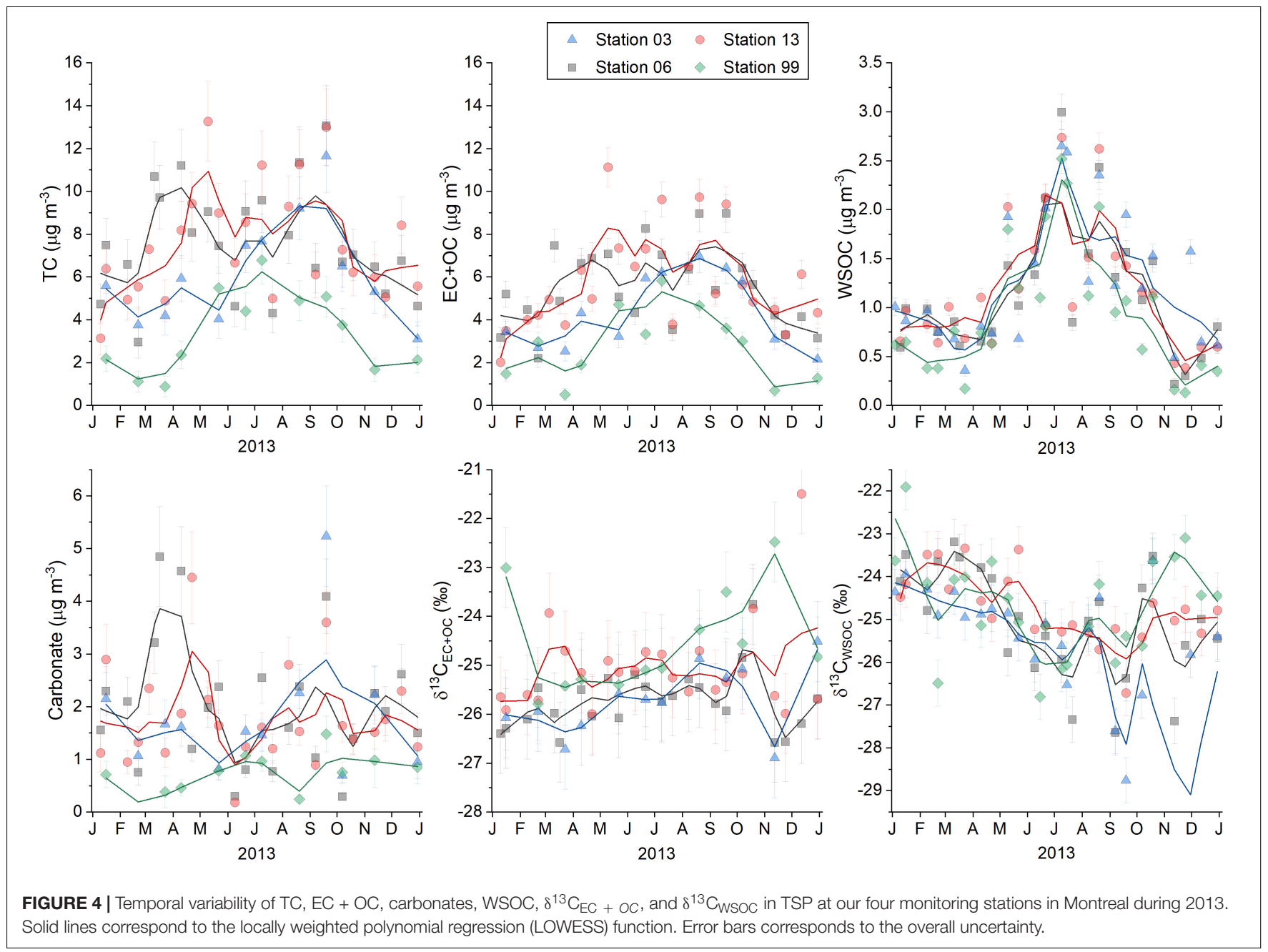

a tagged-species method for apportioning the contributions of anthropogenic sources to the primary-organic-matter (POM) and EC components of $\mathrm{PM}_{2.5}$ in Canada and the United States. The authors calculated that in Montreal the relative contributions of road traffic to the $\mathrm{POM}_{2.5}$ and $\mathrm{EC}_{2.5}$ average concentrations were 27 and $89 \%$, respectively.

Although seasonal patterns indicated that road traffic emissions influenced the OC and the EC fractions, this did not clearly reflect on the corresponding carbon isotope compositions. All stations exhibited roughly constant $\delta^{13} \mathrm{C}_{\mathrm{EC}}+$ OC values during most of the year with a moderate tendency toward more ${ }^{13} \mathrm{C}$-enriched values from January to September (Figure 4). Still, significant differences were observed between October and December: while stations 03 and 06 yielded depleted $\delta{ }^{13} \mathrm{C}_{\mathrm{EC}}+O C$, especially in November and December, highly enriched values were recorded at station 13 and 99. Figure 6 illustrates a seasonal dependence between $\delta^{13} \mathrm{C}_{\mathrm{EC}}+$ OC and the $\mathrm{EC}+\mathrm{OC} / \mathrm{TSP}$ fractions: (i) the increase of the $\mathrm{EC}+\mathrm{OC}$ fraction during late spring, summer and early autumn is associated to a single dominant source with a $\delta^{13} \mathrm{C} \sim-25 \%$; (ii) during the winter months, the lower $\mathrm{EC}+\mathrm{OC}$ fractions suggest the influence of two distinct emission sources, one toward $\delta^{13} \mathrm{C} \sim-27 \%$ and a second one toward $\delta^{13} \mathrm{C} \sim-21 \%$. Previous studies have demonstrated that worldwide emissions from road traffic have $\delta^{13} \mathrm{C}$ that mostly range between -26 and $-24 \%$ (Aguilera and Whigham, 2018), which would be consistent with the single dominant source that we are observing at high EC + OC fractions. The ${ }^{13} \mathrm{C}$-depletion, with values $<-26 \%$, during the winter months was more pronounced at the urban (06 and 13) and industrial (03) stations, which may be related to biomass burning for residential heating and fossil fuel combustion. Wood burning in residential areas is an important source of fine particle emission in Montreal and is one of the main causes of wintertime smog (Jeong et al., 2011; Boulet et al., 2013). The incomplete combustion of $\mathrm{C} 3$ plants generate particles whose $\delta^{13} \mathrm{C}$ typically range from -34.7 to $-24.0 \%$ and fossil fuel combustion particles that usually overlap the upper part of this range (Martinelli et al., 2002; Kawashima and Haneishi, 2012; Aguilera and Whigham, 2018). In contrast, we observed a lower ${ }^{13} \mathrm{C}$-enrichment $\left(\delta^{13} \mathrm{C}>-24 \%\right)$ for some aerosol samples collected at stations 99 and 13, both located on the western part of the island, that is characteristic of coal combustion, soil dust, and marine aerosols ( $\delta^{13} \mathrm{C}$ from -25 to $-18 \%$; e.g., Turekian et al., 2003; Widory et al., 2004; Ceburnis et al., 2011; Miyazaki et al., 2011; 

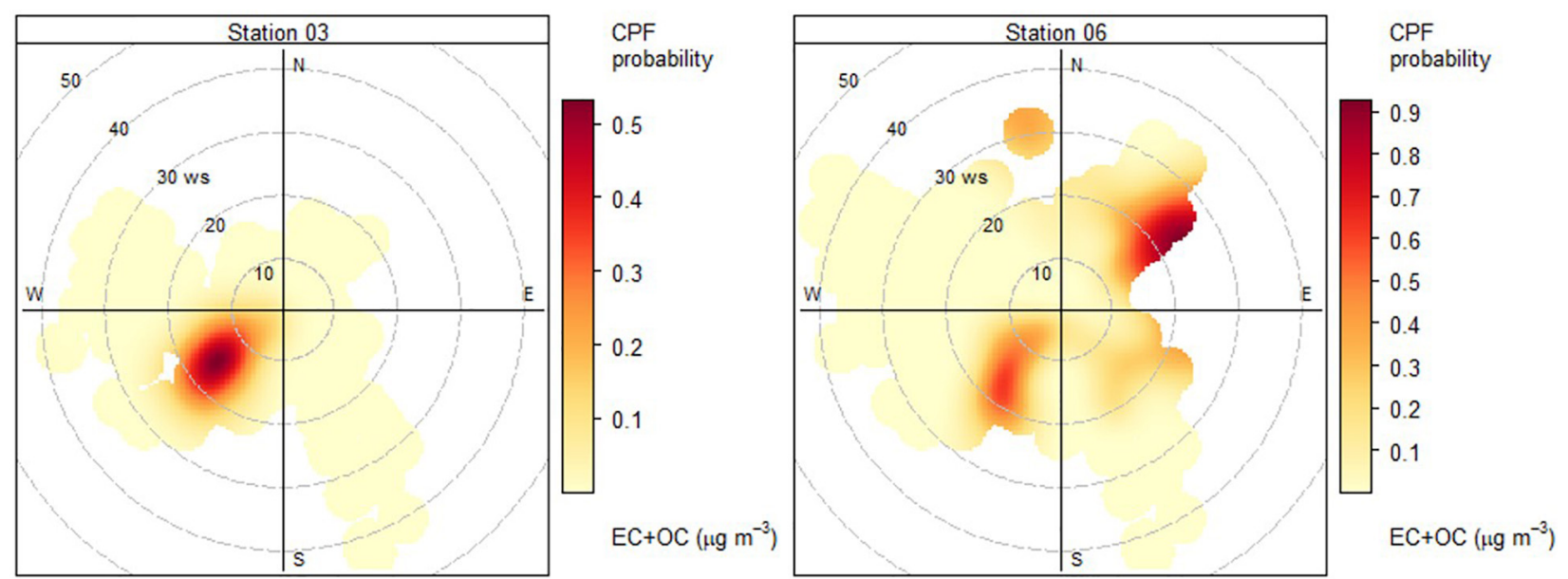

CPF at the 75 th percentile $(=6.2)$

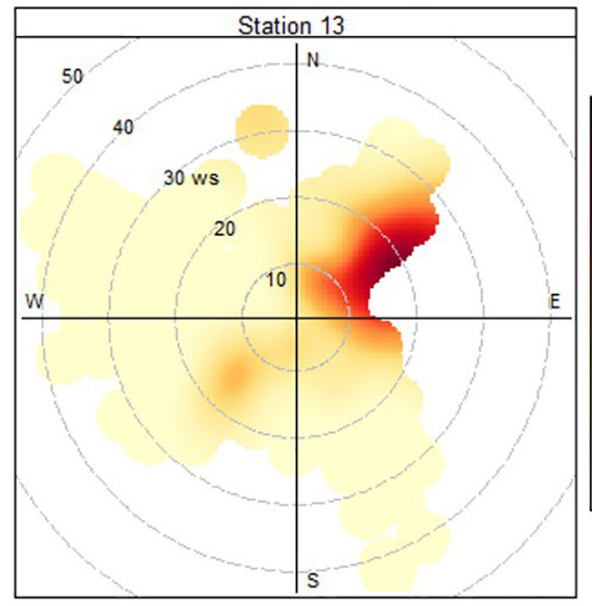

CPF

probability

0.9
-0.8
0.7
0.6
0.5
0.4

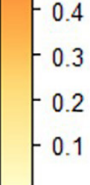

CPF at the 75 th percentile $(=7.3)$

CPF at the 75 th percentile $(=7)$

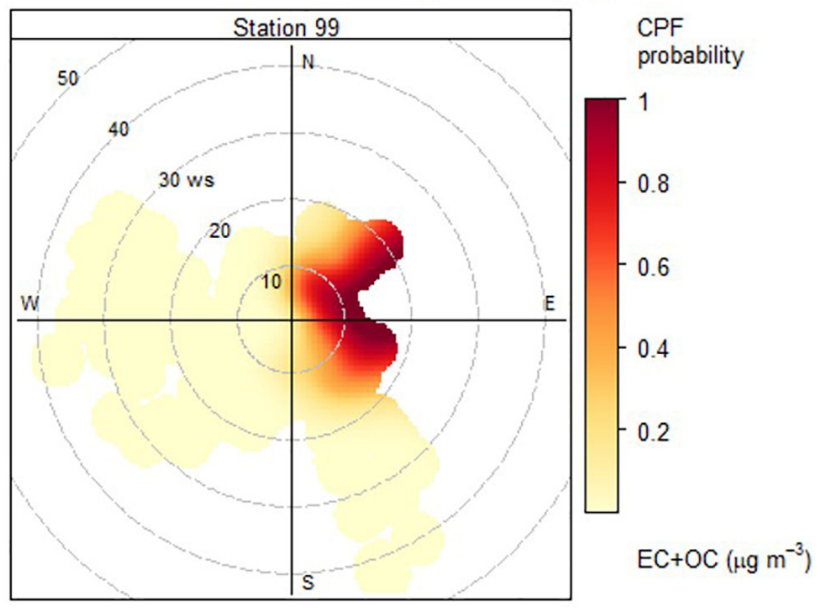

CPF at the 75 th percentile $(=4.7)$

FIGURE 5 | Conditional bivariate probability function (CBPF) at the 75th percentile calculated for the $\mathrm{EC}+\mathrm{OC}$ concentrations at four monitoring stations in Montreal during 2013. WS: wind speed expressed in $\mathrm{km} \mathrm{h}^{-1}$.

Guo et al., 2016; Aguilera and Whigham, 2018). Moreover, these seasonal variabilities for the $\mathrm{C}$ concentrations and corresponding isotope compositions in Montreal's aerosols are distinct from those previously reported in Poland (Górka et al., 2012, 2020) and India (Bikkina et al., 2017), where lower C concentrations associated to more depleted $\delta^{13} \mathrm{C}$ were generally observed in spring and summer. Our results thus indicate that, in Montreal, carbonaceous aerosols are controlled by different dynamics and probably result of emissions from different contamination sources.

\section{Water-Soluble Organic Carbon}

All sampling stations presented similar WSOC seasonal patterns (Figure 4), with low concentrations in winter and early spring that rapidly increase until the summer, followed by a decrease to the minimum values in late autumn. This seasonality was also observed at the background station 99 for TC and EC +OC. This comforts our previous conclusion of a predominant regional origin of the WSOC fraction in Montreal's aerosols, and also comforts the representativeness of station 99 as the regional background monitoring station.

$\delta^{13} \mathrm{C}_{\mathrm{WSOC}}$ showed similar time distributions for all stations (Figure 4), with more positive isotope compositions in winter that tend to decrease from spring to early autumn. Still, some samples collected at station 03 did not follow this pattern at the end of the year, showing a marked depletion in ${ }^{13} \mathrm{C}$ in September, and particularly in November and early December. This behavior is similar to the one observed for $\delta^{13} \mathrm{C}_{\mathrm{EC}}+{ }_{\mathrm{OC}}$, especially in November (Figure 4). These highly depleted $\delta^{13} \mathrm{C}$ values at station 03 were associated to west-northwest winds blowing at $\sim 30 \mathrm{~km} \cdot \mathrm{h}^{-1}$ (Supplementary Figure 7 ), suggesting the influence of relatively distant sources. Numerous industries, including an oil refinery plant and chemical plants, are located $1.5-3 \mathrm{~km}$ west-northwest of station 03 . Moreover, the depletion of both the $\delta^{13} \mathrm{C}_{\mathrm{WSOC}}$ and $\delta^{13} \mathrm{C}_{\mathrm{EC}}+$ OC values was not constant, with a decrease observed from the easternmost station (03) to the 


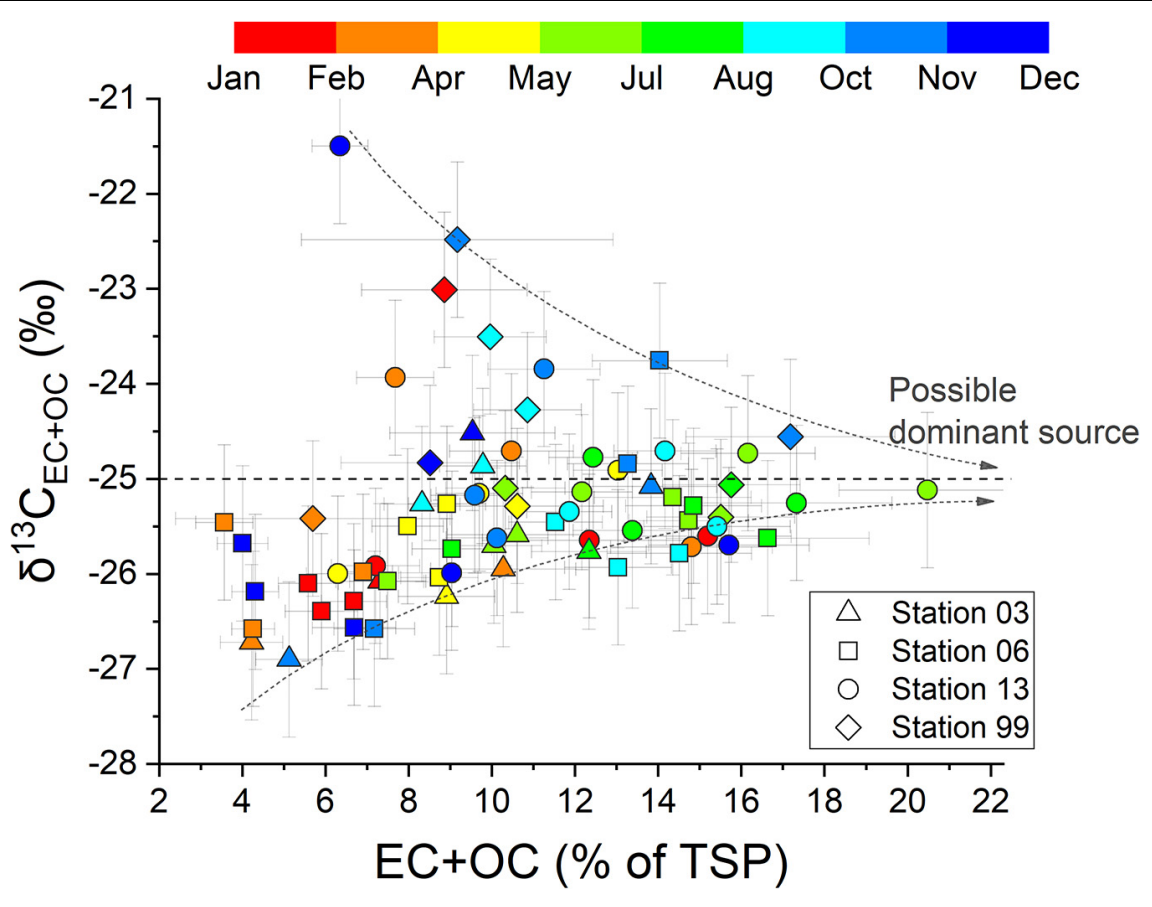

FIGURE 6 | Dependence of $\delta^{13} \mathrm{C}_{\mathrm{EC}}+\mathrm{OC}$ with the $\mathrm{EC}+\mathrm{OC}$ concentrations in TSP samples at four monitoring stations in Montreal during 2013 . Aerosol samples are discriminated by their month of collection. Arrows indicate a possible dominant EC + OC emission source toward the summer months. Error bars corresponds to the overall uncertainty.

westernmost (99) one during the same period, with the highest $\delta^{13} \mathrm{C}$ values measured at station 99 (Figure 4). This suggests that emissions from the industrial activities located in the vicinity of station 03 impacted the carbon isotope composition of carbonaceous aerosols at the other stations (06 and 13), but that this impact decreased and became minimal at the western background station (99). The combustion of liquid fuels (unleaded and regular gasoline, diesel and fuel oil, -29.5 to $-27.6 \%$ ), liquefied petroleum gas (LPG, $-31.7 \%$ ) and natural gas $\left(-41.5\right.$ to $-37.5 \%$ ) generates highly depleted $\delta^{13} \mathrm{C}$ values in gases (e.g., Widory, 2006) that match with the observed values. The combustion of domestic and industrial fuels, such as $\mathrm{n}$-butane, isobutene and propane (-29 to $-28 \%$; Lopez-Veneroni, 2009), as well as C3 biomass burning (up to $-34.7 \%$; e.g., Kawashima and Haneishi, 2012; Garbaras et al., 2015; Guo et al., 2016) also yield compatibles isotope compositions. Interestingly, Porada and Kousha (2016), using an UNMIX model based on VOC concentration data acquired in 2000-2009 at 4 monitoring stations in Montreal (including station 03), defined the chemical profiles of local contaminant sources: hydrocarbons from road traffic, heavy hydrocarbons from contaminated urban soils, emissions from the fugitive evaporation of gasoline and LPG, leakage from the industrial and commercial use of solvents, and the inert, ozone-depleting gases permeating the urban atmosphere. However, the enriched $\delta^{13} \mathrm{C}_{\mathrm{WSOC}}$ we measured in 2013 at station $99(\sim-23.5 \%$ ), as previously discussed, are more compatible with the isotope range of sources that include coal combustion, soil dust, and biogenic marine aerosol, and was probably the result of regional rather than local emissions.
It should also be noted that for all monitoring stations the highest WSOC concentrations corresponded to the aerosol samples collected on July 9, only 3 days after a train carrying 7.7 million liters of petroleum crude oil derailed at LacMégantic, $\sim 200 \mathrm{~km}$ east of Montreal. For 2 days numerous crude oil tanks burnt, emitting gases and particles into the atmosphere (Généreux et al., 2015). We modeled 5-days backtrajectories between July 6 and 9 that showed that air masses changed directions and blew over the accident area before arriving to Montreal at an altitude of $10 \mathrm{~m}$ above ground level on July 9 (Supplementary Figure 9). Moreover, a peak of carbon monoxide (CO), a proxy of incomplete combustion, was observed in Montreal during the same period with a maximum also recorded on July 9 (Supplementary Figure 8). Isotopically, $\delta^{13} \mathrm{C}_{\text {WSOC }}$ values were slightly lower in July for most stations (Figure 4), with several isotope compositions in the -27.4 to $-26.0 \%$ range, which coincides with the ones for the combustion of fossil fuels (Widory, 2006; Aguilera and Whigham, 2018) and crude oil (e.g., Morera-Gómez et al., 2018). Atmospheric emissions from the Lac-Mégantic disaster seems to have only impacted the WSOC fraction of Montreal's aerosols, although slightly higher TC and EC + OC concentrations were also observed on July 9 (Figure 4). Still, this slight increase in the TC and $\mathrm{EC}+\mathrm{OC}$ concentrations did not translate into any noticeable isotope shift in the corresponding $\delta^{13} \mathrm{C}$ (Figure 4).

Similarly to the other carbon fractions, WSOC seasonality in Montreal was opposite to the ones for other regions worldwide, such as Hong Kong, India, Maldives, Switzerland or China (Ho et al., 2006; Fisseha et al., 2009; Wang et al., 2010; 
Kirillova et al., 2013), where the highest WSOC concentrations were measured in winter. Most of these studies showed that this resulted of an increased use of coal and biomass for heating purposes during the coldest months, although the authors also argue that local or regional weather conditions may also impact the WSOC seasonality. Still, Pavuluri et al. (2013) reported a WSOC seasonality for the city of Sapporo (Japan; over the period 2009-2010) similar to the one we observed in Montreal, with a gradual concentration decrease from mid-autumn to late winter followed by an increase until early summer. The authors attributed this seasonality to biomass burning, biological emissions and secondary organic aerosol (SOA) formation on local to regional scales. Our results suggest that further studies, including the study of SOA formation and of the influence of regional anthropogenic sources, are required to better understand the WSOC seasonality in Montreal's aerosols.

\section{Sources and Atmospheric Processes Affecting the Seasonality of Carbonaceous Aerosols in Montreal's Atmosphere}

Biomass burning emissions and SOA formation from biogenic VOCs precursors are the two major sources of organic aerosols (de Gouw and Jimenez, 2009; Pavuluri et al., 2013). In densely populated and highly industrialized areas, the corresponding contributions from anthropogenic sources may be up to $50 \%$ (de Gouw et al., 2008; de Gouw and Jimenez, 2009). The CWT calculated for the WSOC concentrations (Figure 7) showed that the highest concentrations observed during the summer corresponded to emissions from regions located in southern Canada and northeastern United States where large urban and industrial areas are found. This conclusion is in agreement with the one drawn by Jeong et al. (2011) in their search of the origin of EC and other long-range transported pollutants, such as secondary nitrates and sulfates, in five Canadian cities that included Montreal. Moreover, while the organic matter and EC contents measured by the Canadian NAPS $\mathrm{PM}_{2.5}$ speciation program showed for Montreal and all southwest network sites (i.e., Saint Anicet, Toronto, Simcoe, Wallaceburg and Windsor) a seasonality similar to the one we highlighted, with higher concentrations in summer, this pattern significantly differs from those of other NAPS sites located elsewhere in Canada (DabekZlotorzynska et al., 2011). A similar seasonality for secondary OC aerosols was been reported for New York, with a maximum peak in July, consistent with the seasonal variations of SOA predicted by global atmospheric chemical transport models for United States (Masiol et al., 2017 and references therein). The organic matter in northeastern United States during summer have mostly be attributed to secondary formation from urban anthropogenic VOCs precursors (Weber et al., 2007; de Gouw et al., 2008). The emissions of biogenic VOCs from plants in warmer months also increase (Masiol et al., 2017) and may also represent a significant pool for the formation of aerosols in Montreal since most of local air masses are typically transported through forested areas northwest of the island during the year (Figure 1). The tendency toward high WSOC values in Montreal was accompanied by a ${ }^{13} \mathrm{C}$-depletion with $\delta^{13} \mathrm{C}_{\text {WsOC }}$ from -24 to $-27 \%$ (Figure 4), indicative of fossil fuel combustion, including road traffic, but also of C3 biomass burning and biogenic emissions (Widory, 2006; Aguilera and Whigham, 2018).

On the other hand, the drop of ozone (Supplementary Figure 10) and hydroxyl radical (Iannone et al., 2003; Masiol et al., 2017) concentrations during winter and the subsequent lower oxidation potential may explain the significant decrease in the WSOC concentrations during that season. The formation of WSOC by oxidation of precursors such as VOCs favors the carbon light isotopes that are primarily oxidized, producing particles with lower $\delta^{13} \mathrm{C}$ (Iannone et al., 2003; Zhang et al., 2019). It follows that secondary compounds tend to be depleted in ${ }^{13} \mathrm{C}$, in opposition to the trend we observed during winter (Figure 4). In contrast, the photochemical aging (i.e., oxidation of compounds in the aerosol phase) of regional aerosols during their transport is expected to introduce a ${ }^{13} \mathrm{C}$-enrichment (Bikkina et al., 2017; Zhang et al., 2019 and references therein), which may thus explain the more positive $\delta^{13} \mathrm{C}_{W S O C}$ values we observed in winter.

The decrease of the carbon concentrations toward the winter months was also observed for the EC + OC fraction (Figure 4). However, apart from a similar pattern detected during the last months of the year, likely related to local pollution events as discussed above, $\delta^{13} \mathrm{C}_{\mathrm{WSOC}}$ and $\delta^{13} \mathrm{C}_{\mathrm{EC}}+$ OC present completely distinct tendencies for most stations (Figure 4). This confirms that these fractions are affected by different emission sources and/or secondary atmospheric processes. Since aging tends to increase the WSOC/OC ratio of aerosols (Aggarwal and Kawamura, 2008; Zhang et al., 2019) we may assume that $\delta^{13} \mathrm{C}_{O C}$ is similar to $\delta^{13} \mathrm{C}_{\mathrm{WSOC}}$ in winter in Montreal. Then, using the isotope mass balance model described in Górka et al. (2020), we can roughly estimate both the EC fraction and its corresponding $\delta^{13} \mathrm{C}_{\mathrm{EC}}$ for the winter season:

$$
\delta^{13} C_{E C}+O C=f_{E C} \times \delta^{13} C_{E C}+f_{O C} \times \delta^{13} C_{O C}
$$

$f_{E C}=\frac{E C}{E C+O C} ; f_{O C}=\frac{O C}{E C+O C} ; m=\frac{\text { WSOC }}{O C}(3-5)$ where $f_{E C}$ and $f_{O C}$ are the EC and OC fractions, respectively, and $m$ is the total OC water-soluble fraction. Assuming that $\delta^{13} \mathrm{C}_{O C}$ $\sim \delta^{13} \mathrm{C}_{\text {WSOC }}$ we can rearrange the equation as follows:

$$
\begin{aligned}
\delta^{13} C_{E C} & =\frac{\delta^{13} C_{E C O C}-\frac{W S O C}{m \times(E C+O C)} \times \delta^{13} C_{W S O C}}{1-\frac{W S O C}{m(E C+O C)}} \\
f_{E C} & =1-\frac{W S O C}{m \times(E C+O C)}
\end{aligned}
$$

Considering the high range of WSOC/OC ratios reported in the literature ( $\mathrm{m}=0.5-0.8$; Wang et al., 2010; Kirillova et al., 2014a; Bikkina et al., 2017; Dasari et al., 2019; Zhang et al., 2019), results yielded consistent EC fractions $>50 \%$ for all monitoring stations, especially stations 06 and 13 with $f_{E C}$ ranging between 60 and $80 \%$. This indicates that, assuming that most of the OC 


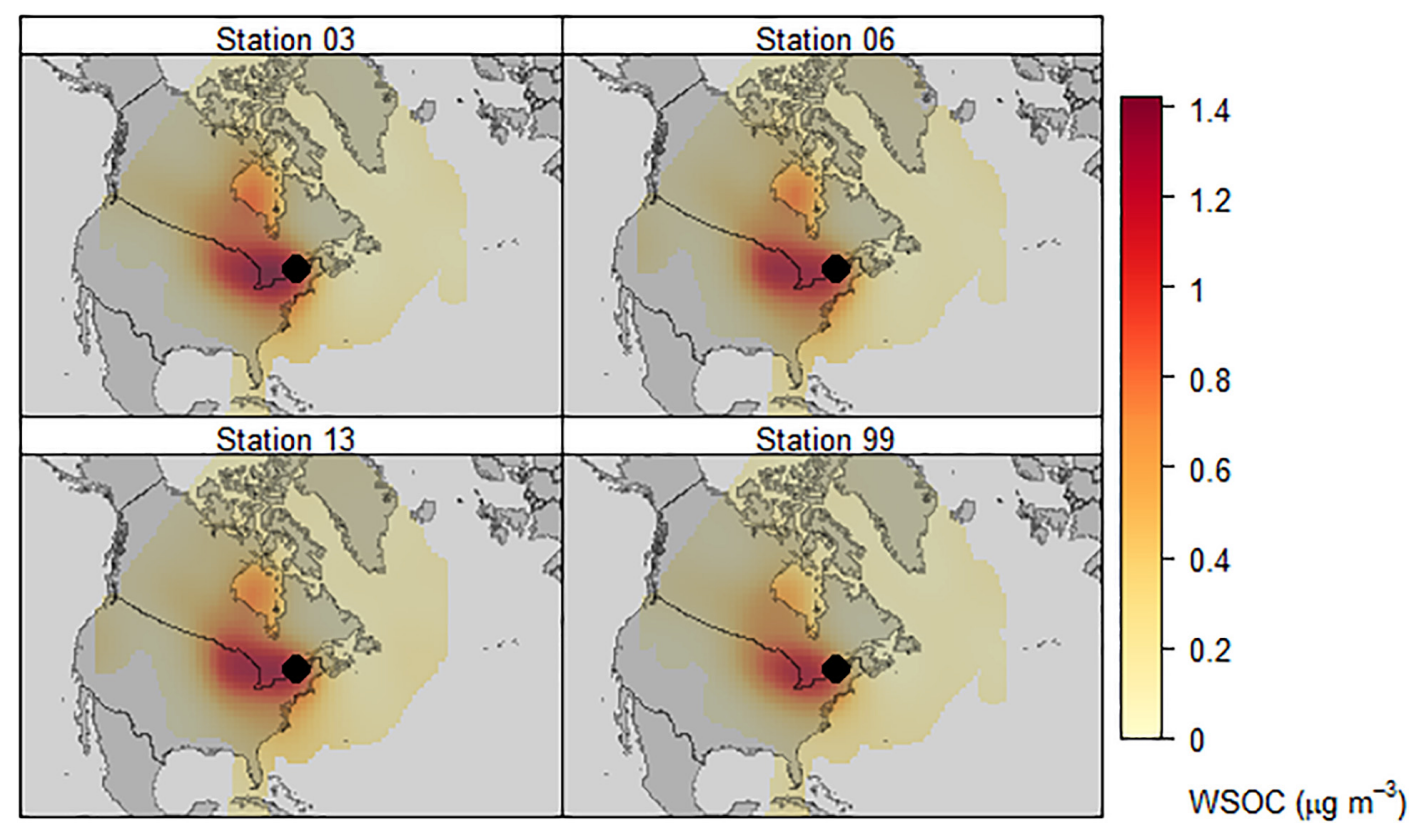

FIGURE 7 | Concentration weighted trajectory (CWT) modeled for WSOC at four monitoring stations in Montreal during 2013.

was water-soluble, the EC fraction was dominant in Montreal during the winter months. Along with the aging of organic aerosols, this may explain the different tendencies observed for the corresponding isotope compositions $\left(\delta^{13} \mathrm{C}_{E C}+O C\right.$ versus $\left.\delta^{13} \mathrm{C}_{\text {WSOC }}\right)$. The calculated $\delta^{13} \mathrm{C}_{E C}$ values were mostly in the range of -34 to $-25 \%$, consistent with the isotope signatures of fossil fuel and C3 plant combustion (e.g., Aguilera and Whigham, 2018). This conclusion is also in line with the increase of biomass burning for residential heating in winter. A winter increase of the EC concentrations from biomass burning had also been previously reported for Montreal by Jeong et al. (2011).

Another key factor that may facilitate the reduction of these carbon fractions in winter is the lower mixing layer heights and possible strong thermal inversions, which limit the dispersion capacity of the atmosphere (Masiol et al., 2017). This may lead to a decrease of the influence of regional sources (clearly associated with the highest concentrations in Montreal; Figure 7) but would enhance the one of local sources, which is compatible, for example, with the typical annual $\mathrm{NO}_{2}$ seasonality in Montreal (Supplementary Figure 6). This increase of the impact of local sources is supported by the fact that the differences in the WSOC concentrations between station 99 and the others increased in winter by up to $40 \%$, a value similar to the one observed for the $\mathrm{EC}+\mathrm{OC}$ fraction, in contrast to the one observed at the annual scale (15-24\%, section "Characteristics of the Carbon Fractions").

\section{CONCLUSION}

Our study details a fast and simple, but precise and accurate, method for online and simultaneous characterizing aerosol WSOC content and corresponding stable $\mathrm{C}$ isotope composition $\left(\delta^{13} \mathrm{C}_{\text {WSOC }}\right)$. To our knowledge, this was the first time the $\delta^{13} \mathrm{C}_{\text {WSOC }}$ was characterized for Canadian aerosols.

The analysis of aerosols samples from different monitoring stations disseminated in Montreal and collected during 2013, showed that the dynamics of carbonaceous aerosols, and particularly their WSOC fraction, is complex and appear to be controlled by different emission sources, atmospheric processes and weather conditions. Still, the added value of the carbon stable isotope geochemistry, studying the $\delta^{13} \mathrm{C}$ of different carbonaceous fractions, allowed to better constrain their origin(s) and dynamics.

The EC + OC concentrations were characterized by low values in winter and maximum values in spring, summer and early autumn. This fraction (EC + OC/TSP) followed a seasonal dependence of its isotope composition: while road traffic was dominant toward summer months with a $\delta^{13} \mathrm{C}_{E C}+$ OC signature $\sim-25 \%$ and higher EC + OC percentages, two opposite trends were observed in winter with the lowest $\mathrm{EC}+\mathrm{OC}$ percentages: (1) a ${ }^{13}$ C-depletion $\left(\delta^{13} C_{E C}+O C<-26 \% 0\right)$ at the urban and industrial stations, suggesting the influence of biomass burning for residential heating and fossil fuel combustion and (2) a ${ }^{13} \mathrm{C}$ enrichment $\left(\delta^{13} \mathrm{C}_{E C}+O C>-24 \%\right.$ ) ) at the background station and sometime at station 13 , likely related to a regional influence.

WSOC showed a similar seasonal pattern for all stations with low concentrations in winter, early spring and late autumn that rapidly increased until the summer months. Our result suggest that this seasonality was governed by higher anthropogenic contributions from southern Canada and northeastern United States regions and probable biogenic emission in warm months, whereas the lower oxidation potential and weather conditions may explain the observed winter decrease in the WSOC concentrations. This seasonality was accompanied 
by a ${ }^{13} \mathrm{C}$-depletion in summer, probable due to higher fossil fuel and biogenic contributions, whereas more enriched isotope compositions in winter appeared to result of the photochemical aging of regional aerosols.

Finally, we evidenced the influence of local industrial emissions late in 2013 and also the impact of emissions associated to the rail disaster that occurred at Lac-Mégantic on July 6 on the WSOC concentrations recorded in Montreal.

\section{DATA AVAILABILITY STATEMENT}

The original contributions presented in the study are included in the article/Supplementary Material, further inquiries can be directed to the corresponding author.

\section{AUTHOR CONTRIBUTIONS}

YM-G contributed to conceptualization, methodology, validation, formal analysis, investigation, data curation, writing original draft, visualization, and funding acquisition. ZC contributed to writing - review and editing. DW contributed to conceptualization, investigation, resources, writing - review and editing, supervision, project administration, and funding

\section{REFERENCES}

Aggarwal, S. G., and Kawamura, K. (2008). Molecular distributions and stable carbon isotopic compositions of dicarboxylic acids and related compounds in aerosols from Sapporo, Japan: implications for photochemical aging during long-range atmospheric transport. J. Geophys. Res. Atmos. 113:D14301. doi: 10.1029/2007JD009365

Aguilera, J., and Whigham, L. D. (2018). Using the 13C/12C carbon isotope ratio to characterise the emission sources of airborne particulate matter: a review of literature. Isotopes. Environ. Health Stud. 54, 573-587. doi: 10.1080/10256016. 2018.1531854

Alastuey, A., Querol, X., Plana, F., Viana, M., Ruiz, C. R., Sánchez de la Campa, A., et al. (2006). Identification and chemical characterization of industrial particulate matter sources in southwest Spain. J. Air Waste Manag. Assoc. 56, 993-1006. doi: 10.1080/10473289.2006.10464502

Aldabe, J., Elustondo, D., Santamaria, C., Lasheras, E., Pandolfi, M., Alastuey, A., et al. (2011). Chemical characterisation and source apportionment of PM2.5 and PM10 at rural, urban and traffic sites in Navarra (North of Spain). Atmos. Res. 102, 191-205. doi: 10.1016/j.atmosres.2011.07.003

Aldhaif, A. M., Lopez, D. H., Dadashazar, H., and Sorooshian, A. (2020). Sources, frequency, and chemical nature of dust events impacting the United States East Coast. Atmos. Environ. 231, 117456. doi: 10.1016/j.atmosenv.2020.11 7456

Anderson, R. S., Iannone, R., Thompson, A. E., Rudolph, J., and Huang, L. (2004). Carbon kinetic isotope effects in the gas-phase reactions of aromatic hydrocarbons with the $\mathrm{OH}$ radical at $296 \pm 4 \mathrm{~K}$. Geophys. Res. Lett. 31:L15108. doi: 10.1029/2004GL020089

Asa-Awuku, A., Moore, R. H., Nenes, A., Bahreini, R., Holloway, J. S., Brock, C. A., et al. (2011). Airborne cloud condensation nuclei measurements during the 2006 texas air quality study. J. Geophys. Res. Atmos. 116:D11201. doi: 10.1029/ 2010JD014874

Au Yang, D., Cartigny, P., Desboeufs, K., and Widory, D. (2019). Seasonality in the Delta S-33 measured in urban aerosols highlights an additional oxidation pathway for atmospheric SO2. Atmos. Chem. Phys. 19, 3779-3796. doi: 10.5194/ acp-19-3779-2019

Batterman, S., Ganguly, R., Isakov, V., Burke, J., Arunachalam, S., Snyder, M., et al. (2014). Dispersion modeling of traffic-related air pollutant exposures and health acquisition. All authors contributed to the article and approved the submitted version.

\section{FUNDING}

This work also received funding through a postdoctoral fellowship granted to YM-G by the UQAM Faculty of Science.

\section{ACKNOWLEDGMENTS}

The authors wish to thank Jean-François Hélie and Agnieszka Adamowicz for their analytical support. Special thanks to the Ville de Montréal for providing aerosol samples from their monitoring network. We would like to thank the three reviewers for their valuable suggestions and comments.

\section{SUPPLEMENTARY MATERIAL}

The Supplementary Material for this article can be found online at: https://www.frontiersin.org/articles/10.3389/fenvs. 2021.622521/full\#supplementary-material

effects among children with Asthma in Detroit, Michigan. Transp. Res. Rec. 2452, 105-113. doi: 10.3141/2452-13

Bikkina, S., Andersson, A., Ram, K., Sarin, M. M., Sheesley, R. J., Kirillova, E. N., et al. (2017). Carbon isotope-constrained seasonality of carbonaceous aerosol sources from an urban location (Kanpur) in the Indo-Gangetic Plain. J. Geophys. Res. Atmos. 122, 4903-4923. doi: 10.1002/2016JD025634

Boulet, D., Melançon, S., and Mallet, R. (2013). Air Quality in Montréal. 2013 Environmental Assessment Report. Ville de Montréal, Service de l'environnement, Division de la Planification et du Suivi Environnemental, Réseau de Surveillance de la qualité de l'air (RSQA), Ottawa: Library and Archives Canada.

Brook, J. R., Dann, T. F., and Burnett, R. T. (1997). The relationship among TSP, PM(10), PM(2.5), and inorganic constituents of atmospheric particulate matter at multiple Canadian locations. J. Air Waste Manag. Assoc. 47, 2-19. doi: 10.1080/10473289.1997.10464407

Cao, J., Chow, J. C., Tao, J., Lee, S., Watson, J. G., Ho, K., et al. (2011). Stable carbon isotopes in aerosols from Chinese cities: influence of fossil fuels. Atmos. Environ. 45, 1359-1363. doi: 10.1016/j.atmosenv.2010.10.056

Carslaw, D. C. (2015). The Openair Manual - Open-source Tools for Analysing Air Pollution Data. Manual for version 1.1-4. Available online at: http://www. openair-project.org (accessed May 7, 2017).

Ceburnis, D., Garbaras, A., Szidat, S., Rinaldi, M., Fahrni, S., Perron, N., et al. (2011). Quantification of the carbonaceous matter origin in submicron marine aerosol by 13C and 14C isotope analysis. Atmos Chem. Phys. 11, 8593-8606. doi: 10.5194/acp-11-8593-2011

Ceburnis, D., Masalaite, A., Ovadnevaite, J., Garbaras, A., Remeikis, V., Maenhaut, W., et al. (2016). Stable isotopes measurements reveal dual carbon pools contributing to organic matter enrichment in marine aerosol. Sci. Rep. 6:36675. doi: 10.1038/srep36675

Cesari, D., Donateo, A., Conte, M., Merico, E., Giangreco, A., Giangreco, F., et al. (2016). An inter-comparison of PM2.5 at urban and urban background sites: chemical characterization and source apportionment. Atmos. Res. 174, 106-119. doi: 10.1016/j.atmosres.2016.02.004

Cheng, I., Zhang, L., Blanchard, P., Dalziel, J., and Tordon, R. (2013). Concentration-weighted trajectory approach to identifying potential sources of speciated atmospheric mercury at an urban coastal site in Nova Scotia, Canada. Atmos. Chem. Phys. 13, 6031-6048. doi: 10.5194/acp-13-6031-2013 
Dabek-Zlotorzynska, E., Dann, T. F., Kalyani Martinelango, P., Celo, V., Brook, J. R., Mathieu, D., et al. (2011). Canadian national air pollution surveillance (NAPS) PM2.5 speciation program: methodology and PM2.5 chemical composition for the years 2003-2008. Atmos. Environ. 45, 673-686. doi: 10.1016/j.atmosenv.2010.10.024

Das, A., Krishna, K. V. S. S., Kumar, R., Saha, M. C., Sengupta, S., and Ghosh, J. G. (2017). Lead isotopic ratios in source apportionment of heavy metals in the street dust of Kolkata, India. Int. J. Environ. Sci. Technol. 15, 159-172. doi: 10.1007/s13762-017-1377-0

Dasari, S., Andersson, A., Bikkina, S., Holmstrand, H., Budhavant, K., Satheesh, S., et al. (2019). Photochemical degradation affects the light absorption of watersoluble brown carbon in the South Asian outflow. Sci. Adv. 5:eaau8066. doi: 10.1126/sciadv.aau8066

de Gouw, J., and Jimenez, J. L. (2009). Organic aerosols in the earth's atmosphere. Environ. Sci. Technol. 43, 7614-7618. doi: 10.1021/es9006004

de Gouw, J. A., Brock, C. A., Atlas, E. L., Bates, T. S., Fehsenfeld, F. C., Goldan, P. D., et al. (2008). Sources of particulate matter in the northeastern United States in summer: 1. Direct emissions and secondary formation of organic matter in urban plumes. J. Geophys. Res. Atmos. 113:D08301. doi: 10.1029/2007JD009243

Decesari, S., Facchini, M. C., Fuzzi, S., and Tagliavini, E. (2000). Characterization of water-soluble organic compounds in atmospheric aerosol: a new approach. J. Geophys. Res. Atmos. 105, 1481-1489. doi: 10.1029/1999JD900950

Delfino, R. J., Murphy-Moulton, A. M., Burnett, R. T., Brook, J. R., and Becklake, M. R. (1997). Effects of air pollution on emergency room visits for respiratory illnesses in Montreal, Quebec. Am. J. Respir. Crit. Care Med. 155, 568-576. doi: 10.1164/ajrccm.155.2.9032196

Dong, S., Gonzalez, R. O., Harrison, R. M., Green, D., North, R., Fowler, G., et al. (2017). Isotopic signatures suggest important contributions from recycled gasoline, road dust and non-exhaust traffic sources for copper, zinc and lead in PM10 in London, United Kingdom. Atmos. Environ. 165, 88-98. doi: 10.1016/j. atmosenv.2017.06.020

Draxler, R. R., and Rolph, G. D. (2015). HYSPLIT (HYbrid Single-Particle Lagrangian Integrated Trajectory) Model Access Via NOAA ARL Ready. College Park, MD: NOAA Air Resources Laboratory.

Environment and Climate Change Canada (2010). National Air Pollution Surveillance (NAPS). Available online at: https://www.canada.ca/en/ environment-climate-change/services/air-pollution/monitoring-networksdata/national-air-pollution-program.html (accessed April 24, 2020).

Fisseha, R., Saurer, M., Jäggi, M., Siegwolf, R. T. W., Dommen, J., Szidat, S., et al. (2009). Determination of primary and secondary sources of organic acids and carbonaceous aerosols using stable carbon isotopes. Atmos. Environ. 43, 431-437. doi: 10.1016/j.atmosenv.2008.08.041

Fisseha, R., Saurer, M., Jäggi, M., Szidat, S., Siegwolf, R. T. W., and Baltensperger, U. (2006). Determination of stable carbon isotopes of organic acids and carbonaceous aerosols in the atmosphere. Rapid Commun. Mass Spectrom. RCM 20, 2343-2347. doi: $10.1002 / \mathrm{rcm} .2586$

Garbaras, A., Masalaite, A., Garbariene, I., Ceburnis, D., Krugly, E., Remeikis, V., et al. (2015). Stable carbon fractionation in size-segregated aerosol particles produced by controlled biomass burning. J. Aerosol Sci. 79, 86-96. doi: 10.1016/ j.jaerosci.2014.10.005

Généreux, M., Petit, G., Maltais, D., Roy, M., Simard, R., Boivin, S., et al. (2015). The public health response during and after the Lac-Mégantic train derailment tragedy: a case study. Disaster Health 2, 113-120. doi: 10.1080/21665044.2014. 1103123

Goldberg, M. S., Burnett, R. T., Stieb, D. M., Brophy, J. M., Daskalopoulou, S. S., Valois, M.-F., et al. (2013). Associations between ambient air pollution and daily mortality among elderly persons in Montreal, Quebec. Sci. Total Environ. 463-464, 931-942. doi: 10.1016/j.scitotenv.2013.06.095

Górka, M., Kosztowniak, E., Lewandowska, A. U., and Widory, D. (2020). Carbon isotope compositions and TC/OC/EC levels in atmospheric PM10 from lower silesia (SW Poland): spatial variations, seasonality, sources and implications. Atmos. Pollut. Res. 11, 1099-1114. doi: 10.1016/j.apr.2020.04.003

Górka, M., Rybicki, M., Simoneit, B. R. T., and Marynowski, L. (2014). Determination of multiple organic matter sources in aerosol PM10 from Wrocław, Poland using molecular and stable carbon isotope compositions. Atmos. Environ. 89, 739-748. doi: 10.1016/j.atmosenv.2014.02.064

Górka, M., Zwolinska, E., Malkiewicz, M., Lewicka-Szczebak, D., and Jêdrysek, M. O. (2012). Carbon and nitrogen isotope analyses coupled with palynological data of PM10 in Wrocław city (SW Poland) - assessment of anthropogenic impact. Isotopes Environ. Health Stud. 48, 327-344. doi: 10.1080/10256016. 2012.639449

Grantz, D. A., Garner, J. H. B., and Johnson, D. W. (2003). Ecological effects of particulate matter. Environ. Int. 29, 213-239. doi: 10.1016/S0160-4120(02) 00181-2

Guo, Z., Jiang, W., Chen, S., Sun, D., Shi, L., Zeng, G., et al. (2016). Stable isotopic compositions of elemental carbon in PM1.1 in north suburb of Nanjing Region, China. Atmos. Res. 168, 105-111. doi: 10.1016/j.atmosres.2015.09.006

Hélie, J.-F. (2009). Elemental and stable isotopic approaches for studying the organic and inorganic carbon components in natural samples. IOP Conf. Ser. Earth Environ. Sci. 5:012005. doi: 10.1088/1755-1307/5/1/012005

Hélie, J.-F., and Hillaire-Marcel, C. (2021). Designing working standards for stable $\mathrm{H}, \mathrm{C}$, and $\mathrm{O}$ isotope measurements in $\mathrm{CO} 2$ and H2O. Rapid Commun. Mass Spectrom. 35:e9008. doi: 10.1002/rcm.9008

Ho, K. F., Lee, S. C., Cao, J. J., Li, Y. S., Chow, J. C., Watson, J. G., et al. (2006). Variability of organic and elemental carbon, water soluble organic carbon, and isotopes in Hong Kong. Atmos. Chem. Phys. 6, 4569-4576. doi: 10.5194/acp-64569-2006

Hsu, Y. K., Holsen, T. M., and Hopke, P. K. (2003). Comparison of hybrid receptor models to locate PCB sources in Chicago. Atmos. Environ. 37, 545-562. doi: 10.1016/S1352-2310(02)00886-5

Iannone, R., Anderson, R. S., Rudolph, J., Huang, L., and Ernst, D. (2003). The carbon kinetic isotope effects of ozone-alkene reactions in the gas-phase and the impact of ozone reactions on the stable carbon isotope ratios of alkenes in the atmosphere. Geophys. Res. Lett. 30:A1684. doi: 10.1029/2003GL017221

Jeong, C.-H., McGuire, M. L., Herod, D., Dann, T., Dabek-Zlotorzynska, E., Wang, D., et al. (2011). Receptor model based identification of PM2.5 sources in Canadian cities. Atmos. Pollut. Res. 2, 158-171. doi: 10.5094/APR.2011.021

Jones, A. M., and Harrison, R. M. (2005). Interpretation of particulate elemental and organic carbon concentrations at rural, urban and kerbside sites. Atmos. Environ. 39, 7114-7126. doi: 10.1016/j.atmosenv.2005.08.017

Karagulian, F., Belis, C. A., Dora, C. F. C., Prüss-Ustün, A. M., Bonjour, S., AdairRohani, H., et al. (2015). Contributions to cities' ambient particulate matter (PM): a systematic review of local source contributions at global level. Atmos. Environ. 120, 475-483. doi: 10.1016/j.atmosenv.2015.08.087

Kawashima, H., and Haneishi, Y. (2012). Effects of combustion emissions from the Eurasian continent in winter on seasonal $813 \mathrm{C}$ of elemental carbon in aerosols in Japan. Atmos. Environ. 46, 568-579. doi: 10.1016/j.atmosenv.2011. 05.015

Kawashima, H., Suto, M., and Suto, N. (2018). Determination of carbon isotope ratios for honey samples by means of a liquid chromatography/isotope ratio mass spectrometry system coupled with a post-column pump. Rapid Commun. Mass Spectrom. 32, 1271-1279. doi: 10.1002/rcm.8170

Kendrick, C. M., Koonce, P., and George, L. A. (2015). Diurnal and seasonal variations of NO, NO 2 and PM 2.5 mass as a function of traffic volumes alongside an urban arterial. Atmos. Environ. 122, 133-141. doi: 10.1016/j. atmosenv.2015.09.019

Kim, D., Jung, J., Lee, H., Choi, S.-H., Lee, S., and Oh, S. (2016). Characterization of sampling artifacts in the measurement of carbonaceous particles using highand low-volume samplers in Daejeon, Korea. Atmos. Environ. 139, 157-166. doi: 10.1016/j.atmosenv.2016.05.029

Kim, H.-S., Jong-Bae, H., Philip, K. H., Holsen, T. M., and Yi, S.-M. (2007). Characteristics of the major chemical constituents Of PM2.5 and smog events in Seoul, Korea in 2003 and 2004. Atmos. Environ. 41, 6762-6770. doi: 10.1016/ j.atmosenv.2007.04.060

Kirillova, E. N., Andersson, A., Han, J., Lee, M., and Gustafsson, Ö (2014a). Sources and light absorption of water-soluble organic carbon aerosols in the outflow from northern China. Atmos. Chem. Phys. 14, 1413-1422. doi: 10.5194/acp-141413-2014

Kirillova, E. N., Andersson, A., Sheesley, R. J., Kruså, M., Praveen, P. S., Budhavant, K., et al. (2013). 13C- and 14C-based study of sources and atmospheric processing of water-soluble organic carbon (WSOC) in South Asian aerosols. J. Geophys. Res. Atmos. 118, 614-626. doi: 10.1002/jgrd.50130

Kirillova, E. N., Andersson, A., Tiwari, S., Srivastava, A. K., Bisht, D. S., and Gustafsson, Ö (2014b). Water-soluble organic carbon aerosols during a full New Delhi winter: isotope-based source apportionment and optical properties. J. Geophys. Res. Atmos. 119, 3476-3485. doi: 10.1002/2013JD020041 
Kirillova, E. N., Sheesley, R. J., Andersson, A., and Gustafsson, Ö (2010). Natural Abundance $13 \mathrm{C}$ and $14 \mathrm{C}$ analysis of water-soluble organic carbon in atmospheric aerosols. Anal. Chem. 82, 7973-7978. doi: 10.1021/ac1014436

Komada, T., Anderson, M. R., and Dorfmeier, C. L. (2008). Carbonate removal from coastal sediments for the determination of organic carbon and its isotopic signatures, $813 \mathrm{C}$ and $\triangle 14 \mathrm{C}$ : comparison of fumigation and direct acidification by hydrochloric acid. Limnol. Oceanogr. Methods 6, 254-262. doi: 10.4319/lom. 2008.6.254

Krummen, M., Hilkert, A. W., Juchelka, D., Duhr, A., Schlüter, H.-J., and Pesch, R. (2004). A new concept for isotope ratio monitoring liquid chromatography/mass spectrometry. Rapid Commun. Mass Spectrom. 18, 2260-2266. doi: 10.1002/rcm.1620

Le Tertre, A., Medina, S., Samoli, E., Forsberg, B., Michelozzi, P., Boumghar, A., et al. (2002). Short-term effects of particulate air pollution on cardiovascular diseases in eight European cities. J. Epidemiol. Community Health 56, 773-779. doi: 10.1136/jech.56.10.773

Liu, J., Mo, Y., Ding, P., Li, J., Shen, C., and Zhang, G. (2018). Dual carbon isotopes (C-14 and C-13) and optical properties of WSOC and HULIS-C during winter in Guangzhou, China. Sci. Total Environ. 633, 1571-1578. doi: 10.1016/ j.scitotenv.2018.03.293

Lopez-Veneroni, D. (2009). The stable carbon isotope composition of PM2.5 and PM10 in Mexico City metropolitan area air. Atmos. Environ. 43, 4491-4502. doi: 10.1016/j.atmosenv.2009.06.036

Malley, C. S., von Schneidemesser, E., Moller, S., Braban, C. F., Hicks, W. K., and Heal, M. R. (2018). Analysis of the distributions of hourly NO2 concentrations contributing to annual average NO2 concentrations across the European monitoring network between 2000 and 2014. Atmos. Chem. Phys. 18, 35633587. doi: 10.5194/acp-18-3563-2018

Martinelli, L. A., Camargo, P. B., Lara, L. B. L. S., Victoria, R. L., and Artaxo, P. (2002). Stable carbon and nitrogen isotopic composition of bulk aerosol particles in a C4 plant landscape of southeast Brazil. Atmos. Environ. 36, 2427-2432. doi: 10.1016/S1352-2310(01)00454-X

Masalaite, A., Remeikis, V., Garbaras, A., Dudoitis, V., Ulevicius, V., and Ceburnis, D. (2015). Elucidating carbonaceous aerosol sources by the stable carbon delta C-13(TC) ratio in size-segregated particles. Atmos. Res. 158, 1-12. doi: 10.1016/ j.atmosres.2015.01.014

Masiol, M., Hopke, P. K., Felton, H. D., Frank, B. P., Rattigan, O. V., Wurth, M. J., et al. (2017). Analysis of major air pollutants and submicron particles in New York City and Long Island. Atmos. Environ. 148, 203-214. doi: 10.1016/ j.atmosenv.2016.10.043

McDow, S. R., and Huntzicker, J. J. (1990). Vapor adsorption artifact in the sampling of organic aerosol: face velocity effects. Atmos. Environ. Part Gen. Top. 24, 2563-2571. doi: 10.1016/0960-1686(90)90134-9

Mills, N. L., Donaldson, K., Hadoke, P. W., Boon, N. A., MacNee, W., Cassee, F. R., et al. (2009). Adverse cardiovascular effects of air pollution. Nat. Clin. Pract. Cardiovasc. Med. 6, 36-44. doi: 10.1038/ncpcardiol399

Miyazaki, Y., Fu, P. Q., Kawamura, K., Mizoguchi, Y., and Yamanoi, K. (2012). Seasonal variations of stable carbon isotopic composition and biogenic tracer compounds of water-soluble organic aerosols in a deciduous forest. Atmos. Chem. Phys. 12, 1367-1376. doi: 10.5194/acp-12-1367-2012

Miyazaki, Y., Kawamura, K., Jung, J., Furutani, H., and Uematsu, M. (2011). Latitudinal distributions of organic nitrogen and organic carbon in marine aerosols over the western North Pacific. Atmos. Chem. Phys. 11, 3037-3049. doi: 10.5194/acp-11-3037-2011

Morera-Gómez, Y., Santamaría, J. M., Elustondo, D., Alonso-Hernández, C. M., and Widory, D. (2018). Carbon and nitrogen isotopes unravels sources of aerosol contamination at Caribbean rural and urban coastal sites. Sci. Total Environ. 642, 723-732. doi: 10.1016/j.scitotenv.2018.06.106

Mukherjee, A., and Agrawal, M. (2017). World air particulate matter: sources, distribution and health effects. Environ. Chem. Lett. 15, 283-309. doi: 10.1007/ s10311-017-0611-9

Okin, G. S., Baker, A. R., Tegen, I., Mahowald, N. M., Dentener, F. J., Duce, R. A., et al. (2011). Impacts of atmospheric nutrient deposition on marine productivity: roles of nitrogen, phosphorus, and iron. Glob. Biogeochem. Cycles 25:GB2022. doi: 10.1029/2010GB003858

Pavuluri, C. M., and Kawamura, K. (2017). Seasonal changes in TC and WSOC and their 13C isotope ratios in Northeast Asian aerosols: land surface-biosphereatmosphere interactions. Acta Geochim. 36, 355-358. doi: 10.1007/s11631-017$0157-3$
Pavuluri, C. M., Kawamura, K., Uchida, M., Kondo, M., and Fu, P. (2013). Enhanced modern carbon and biogenic organic tracers in Northeast Asian aerosols during spring/summer. J. Geophys. Res. Atmos. 118, 2362-2371. doi: 10.1002/jgrd.50244

Perrino, C. (2010). Atmospheric particulate matter. Biophys. Bioeng. Lett 3, 35-43. Pope, C. A., and Dockery, D. W. (2006). Health effects of fine particulate air pollution: lines that connect. J. Air Waste Manag. Assoc. 56, 709-742.

Porada, E., and Kousha, T. (2016). Factorization Methods applied to characterize the sources of volatile organic compounds in Montreal, Quebec. Int. J. Occup. Med. Environ. Health 29, 15-39.

Ramos, Y., St-Onge, B., Blanchet, J.-P., and Smargiassi, A. (2016). Spatio-temporal models to estimate daily concentrations of fine particulate matter in Montreal: kriging with external drift and inverse distance-weighted approaches. J. Expo. Sci. Environ. Epidemiol. 26, 405-414. doi: 10.1038/jes.2015.79

Richter, H., and Howard, J. B. (2000). Formation of polycyclic aromatic hydrocarbons and their growth to soot - a review of chemical reaction pathways. Prog. Energy Combust. Sci. 26, 565-608. doi: 10.1016/S0360-1285(00) 00009-5

Samaali, M., Bouchet, V. S., Moran, M. D., and Sassi, M. (2011). Application of a tagged-species method to source apportionment of primary PM2.5 components in a regional air quality model. Atmos. Environ. 45, 3835-3847. doi: 10.1016/j. atmosenv.2011.04.007

Seinfeld, J. H., and Pankow, J. F. (2003). Organic atmospheric particulate material. Annu. Rev. Phys. Chem. 54, 121-140. doi: 10.1146/annurev.physchem.54. 011002.103756

Smithson, P. A. (2002). IPCC, 2001: climate change 2001: the scientific basis. contribution of working group 1 to the third assessment report of the intergovernmental panel on climate change. Int. J. Climatol. 22, 1144-1144. doi: $10.1002 /$ joc.763

Squizzato, S., Cazzaro, M., Innocente, E., Visin, F., Hopke, P. K., and Rampazzo, G. (2017). Urban air quality in a mid-size city - PM2.5 composition, sources and identification of impact areas: from local to long range contributions. Atmos. Res. 186, 51-62. doi: 10.1016/j.atmosres.2016.11.011

Squizzato, S., and Masiol, M. (2015). Application of meteorology-based methods to determine local and external contributions to particulate matter pollution: a case study in Venice (Italy). Atmos. Environ. 119, 69-81. doi: 10.1016/j. atmosenv.2015.08.026

Subramanian, R., Khlystov, A. Y., Cabada, J. C., and Robinson, A. L. (2004). Positive and negative artifacts in particulate organic carbon measurements with denuded and undenuded sampler configurations special issue of aerosol science and technology on findings from the fine particulate matter supersites program. Aerosol. Sci. Technol. 38, 27-48. doi: 10.1080/02786820390229354

Sudheer, A. K., Aslam, M. Y., Upadhyay, M., Rengarajan, R., Bhushan, R., Rathore, J. S., et al. (2016). Carbonaceous aerosol over semi-arid region of western India: heterogeneity in sources and characteristics. Atmos. Res. 178-179, 268-278. doi: $10.1016 /$ j.atmosres.2016.03.026

Suto, N., and Kawashima, H. (2018). Online wet oxidation/isotope ratio mass spectrometry method for determination of stable carbon isotope ratios of watersoluble organic carbon in particulate matter. Rapid Commun. Mass Spectrom. 32, 1668-1674. doi: $10.1002 / \mathrm{rcm} .8240$

Szidat, S., Jenk, T. M., Gäggeler, H. W., Synal, H.-A., Fisseha, R., Baltensperger, U., et al. (2004). Source apportionment of aerosols by $14 \mathrm{c}$ measurements in different carbonaceous particle fractions. Radiocarbon 46, 475-484. doi: 10. 1017/S0033822200039783

Turekian, V. C., Macko, S. A., and Keene, W. C. (2003). Concentrations, isotopic compositions, and sources of size-resolved, particulate organic carbon and oxalate in near-surface marine air at Bermuda during spring. J. Geophys. Res. Atmos. 108:4157. doi: 10.1029/2002JD002053

Turpin, B. J., Saxena, P., and Andrews, E. (2000). Measuring and simulating particulate organics in the atmosphere: problems and prospects. Atmos. Environ. 34, 2983-3013. doi: 10.1016/S1352-2310(99)00501-4

Uria-Tellaetxe, I., and Carslaw, D. C. (2014). Conditional bivariate probability function for source identification. Environ. Model. Softw. 59, 1-9. doi: 10.1016/ j.envsoft.2014.05.002

Viana, M., Kuhlbusch, T. A. J., Querol, X., Alastuey, A., Harrison, R. M., Hopke, P. K., et al. (2008). Source apportionment of particulate matter in Europe: a review of methods and results. J. Aerosol. Sci. 39, 827-849. doi: 10.1016/j. jaerosci.2008.05.007 
Wang, G., Xie, M., Hu, S., Gao, S., Tachibana, E., and Kawamura, K. (2010). Dicarboxylic acids, metals and isotopic compositions of $\mathrm{C}$ and $\mathrm{N}$ in atmospheric aerosols from inland China: implications for dust and coal burning emission and secondary aerosol formation. Atmos. Chem. Phys. 10, 6087-6096. doi: 10. 5194/acp-10-6087-2010

Watson, J. G., Chow, J. C., Chen, L. W. A., and Frank, N. H. (2009). Methods to assess carbonaceous aerosol sampling artifacts for IMPROVE and other longterm networks. J. Air Waste Manag. Assoc. 59, 898-911. doi: 10.3155/1047-3289. 59.8.898

Weber, R. J., Sullivan, A. P., Peltier, R. E., Russell, A., Yan, B., Zheng, M., et al. (2007). A study of secondary organic aerosol formation in the anthropogenicinfluenced southeastern United States. J. Geophys. Res. Atmos. 112:D13302. doi: 10.1029/2007JD008408

Widory, D. (2006). Combustibles, fuels and their combustion products: a view through carbon isotopes. Combust. Theory Model. 10, 831-841. doi: 10.1080/ 13647830600720264

Widory, D., Roy, S., Le Moullec, Y., Goupil, G., Cocherie, A., and Guerrot, C. (2004). The origin of atmospheric particles in Paris: a view through carbon and lead isotopes. Atmos. Environ. 38, 953-961. doi: 10.1016/j.atmosenv.2003. 11.001

Wu, X., Vu, T. V., Shi, Z., Harrison, R. M., Liu, D., and Cen, K. (2018). Characterization and source apportionment of carbonaceous PM2.5 particles in China - a review. Atmos. Environ. 189, 187-212. doi: 10.1016/j.atmosenv. 2018.06.025

Wurzler, S., Reisin, T. G., and Levin, Z. (2000). Modification of mineral dust particles by cloud processing and subsequent effects on drop size distributions. J. Geophys. Res. Atmos. 105, 4501-4512. doi: 10.1029/1999JD90 0980

Zhang, R., Wang, G., Guo, S., Zamora, M. L., Ying, Q., Lin, Y., et al. (2015). Formation of urban fine particulate matter. Chem. Rev. 115, 3803-3855. doi: 10.1021/acs.chemrev.5b00067

Zhang, W., Zhang, Y.-L., Cao, F., Xiang, Y., Zhang, Y., Bao, M., et al. (2019). High time-resolved measurement of stable carbon isotope composition in watersoluble organic aerosols: method optimization and a case study during winter haze in eastern China. Atmos. Chem. Phys. 19, 11071-11087. doi: 10.5194/acp19-11071-2019

Zhao, Z., Cao, J., Zhang, T., Shen, Z., Ni, H., Tian, J., et al. (2018). Stable carbon isotopes and levoglucosan for PM 2.5 elemental carbon source apportionments in the largest city of Northwest China. Atmos. Environ. 185, 253-261. doi: 10.1016/j.atmosenv.2018. 05.008

Conflict of Interest: The authors declare that the research was conducted in the absence of any commercial or financial relationships that could be construed as a potential conflict of interest.

Copyright (c) 2021 Morera-Gómez, Cong and Widory. This is an open-access article distributed under the terms of the Creative Commons Attribution License (CC BY). The use, distribution or reproduction in other forums is permitted, provided the original author(s) and the copyright owner(s) are credited and that the original publication in this journal is cited, in accordance with accepted academic practice. No use, distribution or reproduction is permitted which does not comply with these terms. 